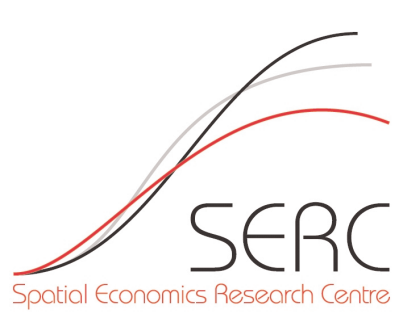

SERC DISCUSSION PAPER 14

\title{
Does Urbanisation Affect Rural Poverty? Evidence from Indian Districts
}

Massimiliano Cali (SERC, Overseas Development Institute and LSE)

Carlo Menon (SERC and LSE)

February 2009 
This work was part of the research programme of the independent UK Spatial Economics Research Centre funded by the Economic and Social Research Council (ESRC), Department for Business, Enterprise and Regulatory Reform (BERR), the Department for Communities and Local Government (CLG), and the Welsh Assembly Government. The support of the funders is acknowledged. The views expressed are those of the authors and do not represent the views of the funders.

(C) M. Cali and C. Menon, submitted 2009 


\title{
Does Urbanisation Affect Rural Poverty? Evidence from Indian Districts
}

\author{
Massimiliano Cali* and Carlo Menon**
}

\section{February 2009}

* SERC, Overseas Development Institute and Department of Geography and Environment, London School of Economics

** SERC and Department of Geography and Environment, London School of Economics

Acknowledgements

We thank Andrew Shepherd, who inspired the main question of the research, and Henry Overman for detailed comments on an earlier draft. Giovanni Favero, Steve Gibbons, Vegard Iversen, Veena Jha, Kunal Sen, Stephen Sheppard, Hugh Wenban-Smith, an anonymous referee and participants at the LSE SERC junior seminar, at the Urban Economics Association conference in New York and at the ISI Annual Conference on Economic Growth and Development in Delhi provided useful comments. Thanks also go to Petia Topalova and Pingali Parthasarathy Rao for sharing some of the data. Financial support by the Chronic Poverty Research Centre is gratefully acknowledged. The usual disclaimer applies. 


\begin{abstract}
Although the high rate of urbanization and the high incidence of rural poverty are two distinct features of many developing countries, we still do not know the effects of the former on the latter. We address this issue by exploring the mechanisms through which urbanization may alleviate rural poverty, disentangling "first round" effects, due to migration of rural poor to cities, and "second round" effects, due to positive externalities of city growth on surrounding rural areas. We test our theoretical predictions on a sample of Indian districts in the period 1981-1999, and find that urbanization has a substantial and systematic poverty reducing effect in surrounding rural areas. This effect is largely attributable to positive spillovers from urbanisation rather than to the movement of the rural poor to urban areas per se. Results using IV estimation suggest that this effect is causal in nature (from urbanisation to rural poverty).
\end{abstract}

Keywords: Rural Poverty, Urbanization, Indian districts, India

JEL Classifications: O12 O18 O2 I3

Data: Indian Census, National Sample Survey, ICRISAT agricultural data 


\section{Introduction}

The typical transformation of an economy from agricultural and mainly rural to industrial and predominantly urban in the process of development has long been a well established fact (Lewis, 1954; Kuznets, 1955). However, the direct implications of this transformation on the economic welfare of the population during this process remain less apparent. In particular, what happens to surrounding rural areas when a city grows? Does the area's population receive economic benefit from it and if so, to what extent? In a period of increasing urbanisation in most developing countries, answers to these questions would bear important implications for development policies.

There is still very little known about the actual economic impact of urbanisation on rural areas. This paper represents one of the first efforts to fill this gap, as it tries to measure the impact of urbanisation on rural poverty in the Indian context. The paper uses district-level panel data between 1981 and 1999 to show that urbanization has been an important determinant of poverty reduction. In our preferred estimations, we find that an increase of 100,000 urban residents in the representative district (around $21 \%$ increase from the mean) implies a decrease of between 3 and 6 percentage points in the share of rural poverty.

This analysis becomes more important when considering that most of the world's poor reside in rural areas, where the incidence of poverty is higher than in urban areas across all developing regions. In 1993 rural areas accounted for $62 \%$ of the world population and for $81 \%$ of the world's poor at the $\$ 1 /$ day poverty line; in 2002 after a period of intensive urbanisation the same figures stood at $58 \%$ and $76 \%$ respectively (Ravallion et al., 2007). ${ }^{1}$ The process of urbanisation (which mostly concerns the developing world) has been accompanied by an unequal distribution of the global reduction in poverty rates. Between 1993 and 2002 while the number of $\$ 1 /$ day poor in rural areas declined by 100 million, that of urban poor increased by 50 million. Ravallion et al. (2007) explain this "urbanisation of poverty" through two related arguments. ${ }^{2}$ First, a large number of rural poor migrated to urban areas; thus ceasing to be rural poor and either they have been lifted out of poverty in the process (through a more productive use of their work) or they have become urban poor. This is a direct (or 'first-round' in Ravallion et al. (2007) terminology) effect of urbanisation on rural poverty. Second, the process of urbanisation also impacts the welfare of those who

\footnotetext{
${ }^{1}$ In fact the actual poverty line used by Ravallion et al. (2007) is $\$ 1.08 /$ day; to save clutter we refer to it as the $\$ 1 /$ day poverty line.

${ }^{2}$ The term "urbanization of poverty" was first introduced by Ravallion (2002).
} 
remain in rural areas through second-round effects. The overall impact of urbanisation on rural poverty is substantial but, in the absence of data on the poverty profile of rural-urban migrants, it is not possible to distinguish between the two effects. We mainly focus on these second-round effects, trying to control for the direct effects of urbanisation on rural poverty.

Distinguishing between first and second-round effects is important. The former involves only a statistical association between urbanization and changes in rural poverty due to the change in residency of some rural poor (who may or may not be lifted out of poverty in their move to the urban areas). This entails no causal link. On the other hand, second-round effects capture the impact of the urban population growth on the rural rate of poverty. Such a relationship is causal in nature and tells us how good or bad urbanisation is for rural poverty. In a developing country context, understanding this relationship is particularly important because most of the population in these countries will continue to be rural for at least another decade and for another three decades in least developed countries (LDCs). ${ }^{3}$ This figure, along with the recognition that poverty has a higher incidence in rural than urban areas, suggests that it is on this rural non-migrant population that the implications of urbanisation will be most important for global poverty reduction in the near future. ${ }^{4}$ The focus on developing countries is essential given that almost the entire future population growth in urban areas (94\% in 2005-2030) is predicted to take place in developing countries (UN, 2008).

We consider Indian urbanisation at the district-level for the period 1981-1999. During this period the country urbanised at a relatively slow rate: the urban population was $23.3 \%$ of the total in 1981 and $27.8 \%$ in 2001 (Government of India, 2001). However, given the sheer size of the Indian population, this moderate increase turned into a massive rise in the absolute number of urban dwellers (126 million). This represents an increase of almost $80 \%$ in the urban population over this period. These figures mask a large variability in urbanisation patterns at the sub-national level; states have urbanised at very different rates. Among the major states, Tamil Nadu increased its share of urban population from $33 \%$ to $44 \%$ between 1981 and 2001, while Bihar maintained the same urbanisation rate over this period (13\%). The differences are also evident in absolute terms: Uttar Pradesh increased its urban population by 28 million people $(+140 \%)$; at the other extreme West Bengal increased its urban population by only 8 million $(+56 \%)$. Not only are the urbanisation dynamics different,

\footnotetext{
${ }^{3}$ Based on calculations on UN (2008) data, developing countries are expected to become more urban than rural in 2018 and LDCs in 2045.

${ }^{4}$ This does not deny the importance of urban poor in global poverty. In fact these represent a substantial and increasing share of poor globally (although still lower than rural poor). However, estimating the effects of urbanisation on urban poverty would require another model altogether and it is left to the future research agenda.
} 
but so is the geographical spread of urban areas. Figure 1 shows that the density of towns is concentrated in Northern India, roughly in the area along the Ganges river and in the SouthEast (Tamil Nadu in particular). Other areas, such as Andhra Pradesh, Madhya Pradesh and the North-West have significantly lower densities. Such variability (both in levels and in changes) is even more remarkable at the district level, as the left hand-side map in figure 2 shows. For instance, a district like Idukki in Kerala increased its urban population by 13,000 (+29\%) between 1981 and 2001, while the urban population in Rangareddi (Andhra Pradesh) increased by 1.6 million (+416\%) and in Pune (Maharashtra) by 2.4 million (+130\%) over the same period. We try to exploit this variability in the subsequent analysis to identify the impact of urbanisation on rural poverty.

In this period India also provides an interesting case in terms of the policy environment and economic performance because the country experienced structural changes in economic policy, rate of growth, and poverty levels. After a long period of economic planning and import substitution industrialisation, the government started reforming the economy toward a more liberal regime in 1991. This change was brought about by the external payment crisis due to the government's deficit spending. Possibly helped by the liberalisation of the economy, economic growth took off since the mid-1980s, and more evidently since 1993, having increased more rapidly than in the 1960s and 1970s (Datt and Ravallion, 2002). Despite disagreements on the extent to which economic growth increased the welfare of India's poor, poverty in India declined steadily in the 1990s, particularly in rural areas (Kijima and Lanjouw, 2003). The geography of the decrease in the share of poor, however, is extremely variegated, as the right hand side map in figure 2 shows. While in many districts more than $30 \%$ of rural population was lifted out of poverty between 1983 and 1999 , for around a quarter of them the share of poverty has remained roughly constant or has even worsened over the same period.

This paper's geographical focus is particularly important as India is the country with the largest number of both rural and urban poor. Its number of \$1/day rural poor in 2002 was over 316 million, representing 36\% of the world's rural poor. Moreover, its urbanisation process is still in its infancy with only $28 \%$ of the population being urban in 2000 . The country is expected to add a further 280 million urban dwellers by $2030 .{ }^{5}$ Thus estimating the impact of urbanisation on rural poverty in India may help identify the potential effects of this expected massive growth of urban population on the world's largest stock of rural poor.

\footnotetext{
${ }^{5}$ This is based on authors' calculations on UN (2008).
} 


\section{Urbanization And Rural Poverty: Channels}

Why would the increase in urban population have an impact on poverty in surrounding rural areas? There are various ways in which urbanisation and rural poverty are linked. We can distinguish between a simple composition effect due to migration of poor from rural to urban areas (first round effect), and a spillover effect due to positive externalities of urbanization on surrounding urban areas (second round effect). In the following, we analyse the main mechanisms through which the latter effect may take place. Then we discuss the way in which we can try to isolate second-round from first-round effects.

\subsection{Second round effects}

There are at least six main indirect channels through which urban population growth may affect rural poverty in surrounding areas: backward linkages, rural non-farm employment, remittances, agricultural productivity, rural land prices and consumer prices.

Backward linkages: An expanding urban area (both in terms of population and income) will generate an increase in the demand for rural goods. For perishable products and in general for those products without spatially integrated markets (e.g. due to high transportation costs), such a demand will typically be met by surrounding rural areas; while the other agricultural products could be provided by locations farther away (ideally not too far). This is linked to an idea that goes back to von Thünen's (1966) theory of concentric circles of agricultural specialisation around cities that is determined by the size of transport costs. Rural locations close to urban areas specialise in high transportation cost goods, while locations farther away specialize in lower transport cost commodities. The farther one moves away from cities the more likely it is for rural communities to be self-subsistent in both agricultural and non-agricultural commodities. This is similar to the pattern found by Fafchamps and Shilpi (2003) for Nepal.

This channel is likely to operate via an income as well as a substitution effect. The former is related to the increased demand for agricultural goods due to higher incomes in urban areas relative to rural areas. Such a higher income is usually explained by urbanisation economies: urban areas have denser markets for products and factors, which raise labour 
productivity and wages over the level of rural areas (see Fujita et al., 1999). The substitution effect relates to the increased share of higher value added products in total agricultural demand typical of more sophisticated urban consumers. Empirical evidence confirms this composition effect. Parthasarathy Rao et al., 2004 found that Indian districts with an urban population over 1.5 million have a significantly higher share of high value commodities than the other districts. Thanh et al. (2008) show that per capita consumption of high value fruit in Vietnam has increased faster in urban than in rural areas over the nineties.

Rural non-farm employment: Expanding urban areas may also favour the diversification of economic activity away from farming, which typically has a positive effect on incomes (see e.g. Berdegue et al., 2001; Lanjouw and Shariff, 2002). This effect is particularly important in rural areas surrounding the cities. Three concomitant effects may explain such increased diversification. First, proximity to cities may allow part of the peripheral urban workforce to commute to the city to work. This in turn generates suburban non-farm jobs in services, such as consumer services and retail trade, which are needed by the growing commuter population. Second, as cities provide dense markets to trade goods and services more efficiently, rural households close to cities may afford to specialise in certain economic activities (based on their comparative advantage), relying on the market for their other consumption and input needs (Fafchamps and Shilpi, 2005). This more extensive specialisation should boost productivity and income (Becker and Murphy, 1992). Third, proximity to urban areas stimulates non-farm activities instrumental to agricultural trade (which is increased by urbanization), such as transport and marketing. Recent evidence from Asia provides strong support for the effect of cities in stimulating high return non-farm employment in nearby rural areas (see Fafchamps and Shilpi, 2003 on Nepal, Deichmann et al., 2008 on Bangladesh and Thanh et al., 2008 on Vietnam). On the other hand, and consistent with this line of argument, isolated rural communities do not tend to specialise and rely on subsistence activities dominated by farming. The growth of urban areas would raise the share of rural areas that are close enough to cities to develop a substantial non-farm employment base.

Remittances: Remittances sent back to rural households of origin by rural-urban migrants constitutes another potentially important second-round effect of urbanization on rural poverty. The vast majority of rural-urban migrants (between $80 \%$ and 90\%) send remittances home although with varying proportions of income and frequency (Ellis, 1998). 
To the extent that urbanization is (partly) fuelled by rural-urban migration, this growth may be associated with larger remittance flows to the rural place of origin. The positive effects of remittances in reducing resource constraints for rural households as well as providing insurance against adverse shocks (as their income is uncorrelated with risk factors in agriculture) have been shown by the literature (Stark, 1980, Stark and Lucas, 1988). On the other hand the migrant's family often provides economic supports (monetary or in kind) to the migrant during his initial stay in the urban area. This support aimed at covering the fixed costs of migration can be interpreted as an investment whose main return is the counter urban-torural remittances flow which is received afterwards (Stark, 1980). This urban-to-rural remittance flow may somewhat reduce the net resources transferred to rural areas by urban workers.

Agricultural productivity: Urbanization and rural poverty can also be linked by the changes in rural labour supply that accompany the urbanisation process. To the extent that rural-urban migration reduces the rural labour supply, this may increase (reduce the decrease of) agricultural labour productivity, given the fixed land supply and diminishing marginal returns to land. ${ }^{6}$ This may pose some upward pressure on rural wages. There is indeed some evidence in India of out-migration from rural areas being associated to higher wages in sending areas (Jha, 2008).

Rural land prices: The growth of cities may increase agricultural land prices (owned by farmers) in nearby rural areas due to the higher demand for agricultural land for residential purposes. This may generate increased income for landowners through sale or lease, or through enhanced access to credit markets, where land acts as collateral. Some evidence from the US indicates that expected (urban) development rents are a relatively large component of agricultural land values in US counties which are near or contain urban areas (Plantinga et al., 2002). The impact on rural poverty through this channel depends on the way this increased income is distributed across the rural population. Typically, if land is very concentrated, this channel is likely to benefit a few landowners, potentially restricting access to waged agricultural employment for the landless population. To illustrate, let us assume the extreme case of all rural land concentrated in the hands of one landowner, who employs labour to

\footnotetext{
${ }^{6}$ In fact Eswaran et al. (2008) show that land to labour ratios decreased in most states in India over 1983-1999 as rural population growth rate more than offset rural-urban migration. In this case our argument would become: to the extent that rural-urban migration reduces the growth of the rural labour supply, this may reduce the decrease of agricultural labour productivity.
} 
cultivate it. If the growth of the nearby city pushes the price of the land above the expected value of the discounted stream of profits from cultivating the land, the landowner will sell it. This would leave all the agricultural labourers in the district unemployed. The net effect on poverty will depend on the extent to which the new use of the land will be able to absorb labour (e.g. via construction-related employment). However, given the constraints to the reallocation of agricultural labour across sectors and the high labour intensity of agriculture, we would expect the net effect on rural poverty to be adverse (i.e. increase in rural poverty) when land is highly concentrated (and vice-versa).

Consumer prices: because the growth of a city is associated with lower consumer prices, this may benefit surrounding rural consumers who have access to urban markets. This effect may be due to increased competition among a larger number of producers in the growing urban area as well as to thicker market effects in both factors' and goods' markets (e.g. Fujita et al., 1999).

A further potential channel may relate to early arguments made by Jacobs (1969) and Dore (1987) that agriculture in rural areas surrounding cities also benefits from spillover effects in technology and marketing. However, to the best of our knowledge, no specific evidence has been provided in support to this view yet.

Table 1: Ex-ante second-round effects of urbanization on rural poverty

\begin{tabular}{|c|c|c|}
\hline & Predicted net effect & Reach of the effect \\
\hline Backward linkages & Negative & Nearby rural \\
\hline $\begin{array}{l}\text { Share of non-farm } \\
\text { employment }\end{array}$ & Negative & Peri-urban \\
\hline Remittances & Negative & Rural \\
\hline $\begin{array}{l}\text { Changes in agricultural } \\
\text { productivity }\end{array}$ & Negative & Rural \\
\hline Rural land prices & $\begin{array}{c}\text { Pos/Neg (depending on land } \\
\text { concentration) }\end{array}$ & Nearby rural \\
\hline Consumer prices & Negative & Nearby rural \\
\hline \multicolumn{3}{|c|}{$\begin{array}{l}\text { Note: Reach of the effect is defined in decreasing order of distance from the urban area as: } \\
\text { rural and Peri-urban. } \\
\text { Source: Authors' elaboration }\end{array}$} \\
\hline
\end{tabular}


poverty is predicted to be negative (i.e. poverty reducing) with the bulk of the effects being felt at a relatively small distance to the urban area (in surrounding rural areas). The next sections will detail the methodology used to test these hypotheses by measuring this total net effect in the case of Indian districts.

\subsection{Disentangling first and second round effects}

As discussed above, we are particularly interested in estimating the second-round effects of urbanization on rural poverty. To do this we first need to disentangle the two effects and then to identify an appropriate way to control for the first round effects in the empirical analysis. This section deals with the former task. Let us assume $N$ distinct geographical units (districts), each with population $P_{i t}$ at time $t$, split between urban $\left(P_{i t}^{U}\right)$ and rural areas $\left(P_{i t}^{R}\right)$, with $i \in[1, N]$. We can characterise the incidence of poverty $\left(H_{i t}^{R}\right)$ in rural areas in district $i$ at time $t$ as a function of the urban population of the district and a series of other characteristics of the district (such as its total population, specific policies, etc.), represented by the vector $X$ :

$$
H_{i t}^{R}=f\left(P_{i t}^{U}, X_{i t}\right)+\varepsilon_{i t}
$$

Let us assume that natural growth rate is zero and the only changes in the rural-urban split of the population are determined by one (or both) of these two phenomena: intra-district rural-urban migration or rural areas becoming urban (either because they are encompassed by an expanding urban area or because their population has grown sufficiently to upgrade from the status of village to that of town). ${ }^{7}$ Define $\alpha_{\mathrm{t}}$ as the share of poor in the rural population at time $t, \sigma_{\mathrm{t}}$ as the share of rural-urban migrants in rural poor and $\lambda_{\mathrm{t}}$ as the share of rural poor that live in villages that become urban. Define also $\gamma_{t}$ as the share of rural-urban migrants in

\footnotetext{
${ }^{7}$ This does not consider the possibility of inter-district migration, nor of urban-rural migration. The latter is relatively unimportant in influencing the rural-urban split of the population in a country like India. The stock of urban-rural migrants represented less than $1.4 \%$ of total population in the majority of Indian districts in 1991, with mean equal to $1.7 \%$ (based on the Indian districts database at the University of Maryland - see below). Inter-district migration represents instead a substantial share of total migration, in particular rural-urban. In 1991 it accounted for less than $34 \%$ of total migration for the majority of Indian districts (with mean equal to $37 \%$ ); the share of inter-district migration in total rural-urban migration was even larger in 1997 (median 46\%, average 49\%). However, the empirical analysis below rejects the relevance of this type of migration in determining rural poverty. We could reconcile this finding with the model presented here by assuming that the distribution of interdistrict migrants in both the sending and the recipient districts follows the rural-urban distribution of the those district's populations.
} 
total rural population at time $t$ and $\varphi_{t}$ as the share of rural population who live in villages that become urban areas at time $t$ (with $\gamma_{t} \geq \alpha_{t-1} \sigma_{t}$ and $\varphi \geq \alpha \lambda$ ). We can then re-write (1) as:

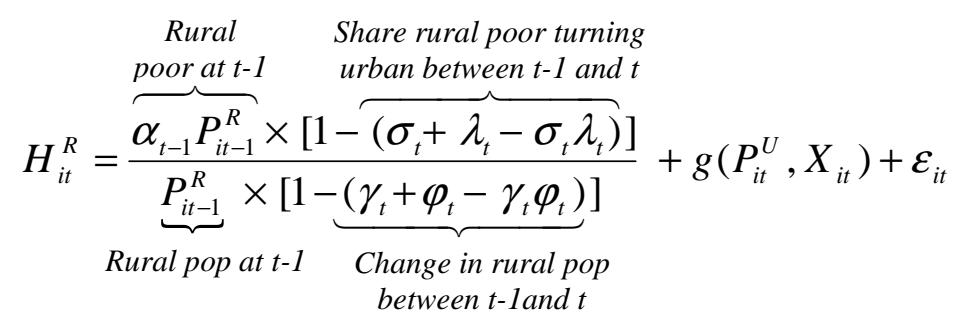

The first term on the right hand side of (2) defines the first-round effects of the growth of urban population on rural poverty. Its numerator represents the number of rural poor at time $t$ as if the change in this number (between $t$ and $t-1$ ) were only due to the change of status of those rural poor (at $t-1$ ) becoming urban dwellers at $t$ (through parameters $\sigma_{\mathrm{t}}$ and $\lambda_{\mathrm{t}}$ ). The denominator represents the total rural population at $t$.

The condition under which this first-round effect decreases rural poverty incidence (ceteris paribus) is $\frac{\alpha_{t-1} P_{i t-1}^{R}\left(1-\sigma_{t}-\lambda_{t}+\sigma_{t} \lambda_{t}\right)}{P_{i t-1}^{R}\left(1-\gamma_{t}-\varphi_{t}+\gamma_{t} \varphi_{t}\right)}<\frac{\alpha_{t-1} P_{i t-1}^{R}}{P_{i t-1}^{R}}$. Ignoring the terms $\sigma_{t} \lambda_{t}$ and $\gamma_{t} \varphi_{t}$ as they are likely to be very small and the subscripts to save clutter this condition becomes:

$$
\sigma+\lambda>\gamma+\varphi
$$

The key variables here are the poverty distributions of both rural-urban migrants and dwellers of rural-urban transitional areas relative to the poverty distribution of the rural population. Expression (3) states that if the distribution of migrants is skewed towards low income individuals - i.e, the incidence of poverty is higher among migrants than non migrants - and if the poverty incidence in rural villages that become urban is higher than that in total rural population of the district then rural-urban migration will directly reduce rural poverty. Recent cross-country evidence by Ravallion et al (2007) seem to be consistent with the validity of condition (3). They find a sizeable negative effect of urbanisation on the incidence of rural poverty and concomitantly an increase in the number of urban poor with urbanisation. Although they cannot isolate the direct effects of rural-urban migration, their findings would be hard to reconcile without condition (3) to be verified. Although there is no evidence establishing empirically the relative size of the parameters in (3), some studies find that those rural areas on the outskirts of (large) urban areas which may benefit economically from this vicinity (e.g. Fafchamps and Shilpi, 2003 for Nepal). This may imply lower levels of rural 
poverty in those peri-urban areas about to be incorporated into urban areas, i.e. $\lambda<\varphi$. This means that the poverty incidence among rural-urban migrants needs to be substantially higher than that among rural non-migrant population for expression (3) to be verified, i.e. $\sigma>\gamma+(\varphi-\lambda)$.

As the main aim of this paper is to estimate the size and direction of the second-round effects of urbanization on rural poverty, we can re-express (2) to control for the direct effects of urbanisation as well as for other covariates of rural poverty:

$$
H_{i t}^{R}\left(P_{i t}^{U} \mid \sigma_{i t}, \gamma_{i t}, \lambda_{i t}, \varphi_{i t}, X_{i t}\right)=h\left(\sigma_{i t}, \gamma_{i t}, \lambda_{i t}, \varphi_{i t}\right)+g\left(P_{i t}^{U}, X_{i t}\right)+\varepsilon_{i t}
$$

This expression represents the basis of the empirical analysis described in the next section. Effectively we need to estimate the partial derivative of $H_{i t}^{R}$ with respect to $P_{i t}^{U}$. The channels described above should underlie the second-round effects that we are trying to capture through this partial derivative.

\section{Empirical methods}

Using a district-level analysis, we try to systematically assess whether and to what extent urbanization in Indian districts during the 1981-1997 period has affected rural poverty in those districts. In order to evaluate the eventual effects of urbanization on the people in extreme poverty, we also use specifications of rural poverty which try to isolate changes in the intensity of poverty for the very poor.

We argue that districts are an appropriate spatial scale for such an analysis in India as all of the first and second-round channels described above are likely to display most of their effects within the district's boundaries. This is consistent with the theoretical discussion above, arguing that the effects of city growth are concentrated in surrounding rural areas. Various pieces of specific evidence on India confirm that this is likely to be the case.

First, evidence suggests that intra-district migration in India is a large component of total rural-urban migration. According to the Census (Government of India, 1991), 62\% of the total stock of permanent internal migrants was intra-district in 1991, although a share of this 
stock was composed of women migrating for marriage reasons. ${ }^{8}$ However, a consistent part of internal migration in India is not captured by the Census because it does not involve change in residence. This may include various forms of temporary migration, such as seasonal and circular as well as commuting. Such a migration may account for an important part of income generation and livelihoods in several rural areas (Deshingkar and Start, 2003, and Deshingkar, 2005). Due to its temporary nature, this migration is likely to be short-distance. In a recent survey of a number of rural villages in two Indian states, Deshingkar and Start (2003) reported that in a number of villages several households were commuting daily to nearby urban locations (although this movement was not registered in the migration data) and in one village, one entire caste took up casual labouring in the urban sector. This does not deny the existence of long-distance migration in India, which in fact was increasing during the nineties (Jha, 2008). However, long distance rural-urban migration is mainly directed to a few growing metropolitan areas, such as Mumbai, Delhi, Bangalore and Chennai, which are excluded from the analysis. ${ }^{9}$ Notwithstanding the importance of intra-district migration, in the empirical section we also test the robustness of the results against the relative size of the intradistrict migrant population.

Second, during the period of analysis (1981-1999) most perishable agricultural goods' markets do not appear to be well integrated at the national or even at the state level in India. This is due to relatively poor transport infrastructure networks and lack of appropriate technology (such as cold storage facilities). ${ }^{10}$ Agricultural produce is often sold in nearby towns and even most trade in livestock tends to occur at a short distance. This is due to lack of infrastructure, which brings livestock marketing costs to distant markets up to 20-30 percent of the sale price (Chandra Mohan Reddy, 2000). As a result, most transactions in live animals take place within the same district (Birthal, 2005). Thus we would expect a consistent share of agricultural trade to occur at a small distance, making districts a suitable spatial scale to capture a substantial part of the first two channels above as well. In line with these ideas, some studies have performed district level analyses to try to capture demand-side effects on agriculture. Parthasarathy Rao et al. (2004) for instance analyse the effects of urbanisation on agricultural diversification into high value commodities, such as fruit, vegetables, dairy products, using districts as the unit of analysis.

\footnotetext{
${ }^{8}$ This is in line with Topalova (2005), who finds limited labour mobility across Indian regions between 1983 and 2000.

${ }^{9}$ We exclude them either because the district which contains them does not have any rural area (e.g. Delhi, Urban Bangalore) or because the effects of their growth are likely to extend well beyond the boundaries of their district.

${ }^{10}$ Infrastructure endowments have to certain extent been upgraded since then.
} 
There is also emerging evidence of increases in land prices in peri-urban and rural areas surrounding urban agglomerates. Land values in those areas may be well above the discounted future stream of income from agricultural activity, inducing several landowners to sell the land (Jha, 2008). ${ }^{11}$

The core idea of the empirical analysis is to assess the effects of urbanization on rural poverty at the district level over time. For that we estimate equation (4) trying to control for the direct effects of urbanisation as well as for other determinants of rural poverty. We use the basic specification:

$$
H_{d t}^{R}=\beta_{0}+\gamma_{d}+\beta_{1} P_{d t-j}^{U}+\beta_{2}\left[\left(\sigma_{d t}+\lambda_{i t}\right) /\left(\gamma_{d t}+\varphi_{i t}\right)\right]+\chi X_{d t}+\varepsilon_{d t}
$$

where $H_{d t}^{R}$ is a measure of rural poverty in district $d$ at time $t, \gamma$ is district fixed effects, $P_{d t-j}^{U}$ is the urban population of district $d$ at time $t-j$ (where $\left.j \in[0,2]\right),\left[\left(\sigma_{d t}+\lambda_{i t}\right) /\left(\gamma_{d t}+\varphi_{i t}\right)\right]$ is a term capturing the direct effects of urbanization on rural poverty, i.e. the term $h\left(\sigma_{i t}, \gamma_{i t}, \lambda_{i t}, \varphi_{i t}\right)$ in (4), and $X$ is a vector of controls, which include other variables likely to have independent impact on rural poverty. The district's urban population is computed as $P_{d t}^{U}=\sum_{i=1}^{N_{d}} u_{i t-j}^{d}$, where $u_{i t-j}^{d}$ is the population of town $i$ in district $d$ at time $t-j$ (where $j \in[0,2])$ and $\mathrm{N}_{\mathrm{d}}$ is the number of cities in district $d$. Given the above discussions, we would expect $\beta_{1}<0$ and $\beta_{2}<0$.

\section{Data and variables}

Data to run specification (5) comes from three main sources: district level measures of poverty are available from various rounds of the Indian household survey data (National Sample Surveys), which have been appropriately adjusted by Topalova (2005) for the 198384, 1987-88, 1993-94 and 1999-2000 rounds of the NSS. ${ }^{12}$ Other district level data, such as

\footnotetext{
${ }^{11}$ All of this evidence seems to be roughly consistent with Fafchamps and Shilpi (2003), who find that in Nepal the effects of proximity on rural areas peters out beyond a four hour radius (in travel time) around cities. Using the boundaries of Indian districts as in 1987, the average district size in our analysis is around 7,300 $\mathrm{Km}^{2}$. If we approximate the district with a circle, a city located in the centre of it would be at around $50 \mathrm{Km}$ from the boundary of the district. It is plausible that in several districts this distance could be covered in about three to four hours on rural Indian roads during the period considered.

${ }^{12}$ Although each survey was carried out over two years, we refer to them with the first of the two years.
} 
population composition come from the Indian districts database at the University of Maryland (which has been extrapolated from the original data in the Indian Census). ${ }^{13}$ Data on town populations are available from various rounds of the Indian Census. In addition, for crop production volumes and values we use the district level database for India available with International Crops Research Institute for semi-Arid Tropics (ICRISAT) from 1980 to 1994 and recently updated by Parthasarathy Rao et al (2004) up to $1998 .{ }^{14}$

The district classification has been modified during the period of analysis, as some districts have been split into two units. Topalova (2005) created a consistent classification by aggregating the 2001 districts originated from the splitting into the district division of 1987 . We conform to this re-aggregation and modify the original population and demographic data accordingly.

Dependent variables: We use two standard Foster Greer Thorbecke (FGT) measures of poverty as dependent variables: the poverty headcount ratio and the poverty gap index. FGT poverty measure for a given rural population is defined as:

$$
H_{\alpha}^{R}=\int_{0}^{z_{R}}\left(\frac{z_{R}-y}{z_{R}}\right)^{\alpha} f(y) d y
$$

where $z_{R}$ is the rural poverty line, and $f(y)$ is the distribution function of monthly per capita expenditure (in this case), with the rural population ordered in ascending order of $y$ (i.e. starting from the poorest). The headcount ratio is computed by setting $\alpha=0$, thus it represents the proportion of the population below the poverty line (poverty rate). However, because this measure does not capture the extent to which households fall short of the poverty line, we also use the poverty gap index. This is computed by setting $\alpha=1$ and is defined as the normalised aggregate shortfall of poor people's consumption from the poverty line. Both measures are increasing in poverty, i.e. a higher value means a higher level of poverty. ${ }^{15}$

\footnotetext{
${ }^{13}$ Available at www.bsos.umd.edu/socy/vanneman/districts/codebook/index.html

${ }^{14}$ The original source of this data is the Government of India, Directorate of Economic and Statistics, Ministry of Agriculture and Cooperation.

${ }^{15}$ In the subsequent analysis we also run some specifications using poverty rate as a control and poverty gap as the dependent variable. This tries to capture a concept more closely related to extreme poverty, as it nets out the share of poor (poverty rate) from the share of the poor weighted by each poor's distance from the poverty line (poverty gap).
} 
Population variables: the Census 1991 (and 2001) classifies towns as all the statutory places with a municipality, corporation, cantonment board or notified town area committee, or, alternatively, places satisfying simultaneously the following three criteria: i) a minimum population of 5,000 ; ii) at least 75 per cent of male working population engaged in nonagricultural pursuits; and iii) a density of population of at least 400 per sq. Km. This is consistent with the classification of the 1981 Census, except for condition iii), which required a minimum population density of 1000 per sq. Km. The year effects should control for eventual problems of consistency of urban data over time. The NSS uses the Census definition to classify urban vs. rural areas, thus ensuring the consistency of data across sources.

There were 5179 towns that met these criteria in 2001 . We calculated the total urban population at the district level, by summing the figures for towns. Due to its peculiar nature, we excluded from the dataset the State of Delhi and the districts of the other megalopolises, Calcutta, Chennai, Bangalore and Mumbai; we also excluded three other districts due to an extraordinary increase in urban population in the period under study, which is extremely likely to be imputable to errors in the data: Anantapur in Andhra Pradesh, Kanniyakumari in Tamil Nadu, and Thane in Maharashtra.

As population data are available only with a ten-year frequency $(1971,1981$, etc.), we estimate the values for the year 1997 by non linear interpolation in order to conduct the analysis for three rounds of the NSS. We first estimate the yearly growth rate in the period 1991-1997, calculating a weighted average of the growth rate of the 1981-1991 and 19912001 periods; we then calculate the 1997 population applying the estimated growth rate to the 1991 level. ${ }^{16}$ In this way we try to reduce the potential endogeneity of the urban population to rural poverty interpolated only using the 1991-2001 growth rate. The main results are also robust to using interpolated 1997 data based only on the 1991-2001 growth rate (results available upon request).

There are 431 districts in Topalova's (2005) original dataset, 409 of which have a positive urban population (at least for one of the three time periods); total population figures are available for only 363 of these, therefore constituting our main sample of analysis; in the year 2001, this sample accounts for a total population of 1,000,053,152 of which $270,153,691$ are urban residents, corresponding to $97 \%$ and $94 \%$ of the Indian total respectively.

\footnotetext{
${ }^{16}$ The exact specification adopted is the following: $\operatorname{pop}(1997)=\operatorname{pop}(1991) *[1+y g(1981-1991) * 0.3+$ $+y g(1991-2001) * 0.7]^{6}$, where $\mathrm{yg}(\mathrm{t}-\mathrm{T})$ is the yearly growth rate of the period $\mathrm{t}-\mathrm{T}$.
} 
Controls: Following the discussion in section 2, we would need data on the poverty profile of rural urban-migrants $\left(\sigma_{d t}\right)$ and of dwellers of areas which are rural at t-1 and become urban at time $\mathrm{t}\left(\lambda_{i t}\right)$ in order to properly estimate $\beta_{2}$ in expression (5), i.e. the direct effects of urbanization on rural poverty. Unfortunately this data is not available, thus we proxy for it by including variables measuring the extent to which migrants (and dwellers of rural areas turning into urban areas) are over- or under-represented among the poor $\left(\sigma_{t}\right)$ relative to the whole rural population $\left(\gamma_{t}\right) .{ }^{17}$ We use two types of such variables.

The first is the district's urban poverty rate $H_{d t}^{U}$. To see why, let us re-express $H_{d t}^{U}$ on the basis of the variables in question. Consider that $H_{d t}^{U}$ depends on the urban poverty at $t-1$, on the share of rural-urban migrants whose income in the urban sector is below the urban poverty line and the change in the poverty rate of previous urban dwellers. ${ }^{18}$ Dropping the subscript $d$ to save clutter, we have:

$$
H_{t}^{U}\left(\pi_{t}, P_{t-1}^{R}, \gamma_{t}, \sigma_{t}\right)=\frac{\psi_{t-1} P_{t-1}^{U}+\rho_{1}\left(\pi_{t}\right)\left(\gamma_{t}-\alpha_{t-1} \sigma_{t}\right) P_{t-1}^{R}+\rho_{2}\left(\pi_{t}\right) \alpha_{t-1} \sigma_{t} P_{t-1}^{R}+\Delta \psi_{t}\left(\pi_{t}\right) P_{t-1}^{U}}{P_{t-1}^{U}+P_{t-1}^{R}}
$$

where $\psi_{t-1}$ is the urban poverty rate at time $t-1, \rho_{1}$ and $\rho_{2}$ are respectively the share of non-poor rural migrant $\left(\gamma_{t}-\alpha_{t-1} \sigma_{t}\right)$ at time $t$ as a function of $\pi_{t}$ and the share of poor rural migrants $\alpha_{t-1} \sigma_{t}$ at time $t$ who have become urban poor at time $t ; \Delta \psi_{t}$ is the change in poverty rate (between $t-1$ and $t$ ) of the existing stock of urban population at $t-1$, and $\pi_{t}$ is the urbanization rate at time $t$. From this expression it follows that $\rho_{1} \leq \rho_{2}$ and $\partial \rho_{1} / \partial \pi_{t}<0$, $\partial \rho_{2} / \partial \pi_{t}<0$. For any values of $\pi_{t}$ we can compute the condition for which $H_{t}^{U}<H_{t-1}^{U}$ (i.e. a reduction in the urban poverty rate between $t-1$ and $t$ ) as:

$$
\begin{aligned}
& z\left(\sigma, \gamma \mid \pi_{t}\right)=\alpha \sigma\left(\rho_{1}-\rho_{2}\right)+\gamma\left(\psi-\rho_{1}\right)>\Delta \psi P_{t-1}^{U}\left(P_{t-1}^{R}\right)^{-1} \\
& \text { with } \partial z / \partial \sigma \leq 0\left(\text { as } \rho_{1} \leq \rho_{2}\right) \text { and } \partial z / \partial \gamma \leq 0 \text { if } \psi \leq \rho_{1} .
\end{aligned}
$$

\footnotetext{
${ }^{17}$ Note that for ease of exposition in the following discussions on the direct effects of urbanisation on rural poverty we refer only to rural-urban migrants and not to those who live in villages that become urban areas. ${ }^{18}$ For the sake of simplicity we do not consider here rural-to-urban transformation of villages. Adding it would not change the basic argument.
} 
Equation (7) implies that for any given value of urban economic growth at time $t$, urban poverty is more likely to have decreased between $t$ and $t-1$ the lower the share of rural poor that migrated to the urban areas during this period $\left(\sigma_{t}\right)$. This is explained by the fact that the probability of poor rural-urban migrants becoming urban poor (after migrating) is higher than the same probability for non-poor rural-urban migrants. On the other hand a smaller rural-urban migrant population will decrease urban poverty only if the incidence of poverty in this population, once it becomes urban, is larger than the pre-existing incidence of poverty in the urban area $\left(\psi \leq \rho_{1}\right)$. Condition (7) therefore implies that the evolution of urban poverty over time should capture the evolution of the parameters $\gamma$ and $\sigma$ at time $t$ for any given value of $\pi_{t}$. This means that at any given time urban poverty should capture the combined effect of economic growth and of the direct effects of urbanisation on rural poverty (the term $h\left(\sigma_{i t}, \gamma_{i t}\right)$ in $\left.(4)\right) .^{19}$

We also control for the first-round effects of urbanization on rural poverty through the socio-demographic composition of the rural population (i.e. age and literacy). Again, this is an indirect form of control and is probably less effective than the share of urban poor in capturing first-round effects. The rationale behind it relies on the assumption that the income distribution of migrants can be expressed as a function of the migrants' age composition. Other things being equal, poverty incidence tends to be lower among young adults (i.e. 1534), as they represent the most productive age class. Therefore the higher the share of young adults in the total migrant population (relative to their share in the rural population) the lower the probability that urbanisation will directly reduce rural poverty. Rewriting expression (3) (without considering rural areas becoming urban for ease of exposition) we have: $\frac{\sigma}{\lambda}\left(\lambda_{15-34}\right)>1$, with $\partial \frac{\sigma}{\lambda} / \partial \lambda_{15-34}<0$, where $\lambda_{15-34}$ is the share of people aged 15-34 in total migrants relative to their share in the rural population. The same argument can be applied to literate migrants. As we do not observe the composition of the migrants' population, we can only control for it indirectly through the composition of the actual rural population. This is based on the plausible assumption that the change in the number of young adults in the rural population is inversely related to the change in their number in the rural-urban migrant population in the same period.

\footnotetext{
${ }^{19}$ Following the criticism of Hasan et al. (2006) on the potential bias in Indian urban poverty data at the district level, we use urban poverty at the regional level, which is a Census-based aggregation of a few districts together.
} 
This assumption is supported by the results of regressing the 1981-91 change in the urban population in the 15-34 age group $\Delta P_{15-34}^{U}$ on the change in the rural population in the same age group $\Delta P_{15-34}^{R}$ (controlling for changes in district's total population and total population in 1981):

$$
\begin{array}{ccccc}
\Delta P_{15-34}^{U}= & -4954 & -1.038 \Delta P_{15-34}^{R} & +0.2554 \Delta P^{\text {tot }} & +0.0123 P_{t-10}^{\text {tot }} \\
& (2.57) & (29.44) & (38.71) & (11.93) \\
\mathrm{N}=334 & \mathrm{R}^{2}=0.97 \quad \text { (robust t-statistics in parenthesis) }
\end{array}
$$

The coefficient of $\Delta P_{15-34}^{R}$ is not statistically different from - 1 indicating that changes in the rural population are reflected in mirror changes in the urban population (through either rural-urban migration or rural-to-urban change in status of villages).

Obviously, the incidence of young adults (as well as literates) in the rural population also directly and positively affects rural income and thus has a direct impact on the poverty rate. Therefore this variable will capture two contrasting effects on rural poverty: a first-order poverty reducing effect and a second-order poverty increasing effect (which should capture part of the direct effect of urbanisation on rural poverty). It should be clear that the ability to control for first round effects of these two types of variables (urban poverty rate and sociodemographic characteristics) is only residual to their direct relationship with rural poverty. Thus they are not likely to fully control for the first round effects of urbanisation on rural poverty. However, to the extent that they can control for at least part of these effects, the direction of change in the urban population coefficient after the inclusion of these variables should provide an idea of the likely intensity of first-round effects.

Aside from the controls of first-round effects, we need to control for any other determinants of rural poverty. The two variables which should control for the composition of the rural population are the number of people in the age group 15-34, and the proportion of literates in this age group. The latter variable is meant to capture the level of literacy of the most productive part of the population, following the idea that the most powerful influence of education on income and poverty is through its labour market effect. We also include in some specifications the share of rural population which is reported as scheduled castes and scheduled tribes, as this is expected to have an independent (adverse) effect on poverty.

However it is likely that other unobserved factors affect the relationship under scrutiny. We exploit the panel dimension of our dataset to deal with that. First, we include 
district fixed effects, which absorb any time-invariant component at the district level, such as geographical position, climatic factors, natural resources, etc. Second, we add a whole set of state-year dummies, which control for state-specific time-variant shocks (including economic dynamics and policies). The inclusion of these controls may still not completely account for three other sources of potential bias in the coefficient of interest $\beta_{1}$ (capturing the second-order effects of urbanization on rural poverty in (5)).

First, there may be unobserved time varying district-specific shocks which may affect both rural poverty and urban population. For example there may be a localised shock (e.g. the election of an effective district government) which spurs district's economic growth. As economic growth is generally associated with urbanisation, this may foster urbanization while reducing rural poverty at the same time. This omitted variable problem would imply a spurious negative association between the two variables. Data on income per capita at the district level is not available to us. As economic growth directly affects urban poverty (as described above) the inclusion of the urban poverty rate in the controls should minimise this problem.

Second, unobserved time varying rural specific shocks may affect urbanisation via increases in agricultural productivity. This view is supported by a long-standing argument in development economics that a country's urbanisation (and industrialisation) process is fuelled by increasing agricultural productivity (e.g. Nurske, 1953). In closed economies an expanding urban population requires increases in productivity of the rural sector in order to be sustained. However, Matsuyama (1992) shows that in open economies this need not be the case, as they may rely on agricultural import for their subsistence (as in the case of the East Asian newly industrialised economies). In our case, districts can probably be considered as small open economies, which can trade across borders in most agricultural markets, thus this potential source of bias may not be very relevant in this analysis. ${ }^{20}$ In line with this Fafchamps and Shilpi (2003) do not find that agricultural productivity of nearby rural areas is an important determinant of city size in Nepal. To be on the safe side, we also control for a measure of agricultural productivity. The variable is constructed as the sum of the total quantities of 22 different crops produced in a given district, multiplied by the average India-wise price of the respective crop in the same year and divided by the district's rural population. We use an India-wise price instead of district specific prices to minimise both the data gaps (which are

\footnotetext{
${ }^{20}$ This argument is not necessarily at odds with the district-level backward linkages channel described above. Urban areas tend to import agricultural products relatively more by surrounding rural areas, but this does not rule out that they can rely on inter-district agricultural trade as well.
} 
several for the latter) and the potential endogeneity of districts' prices to rural poverty. This is in some way an extra control because it may eat up some of the effects of urbanization on rural poverty, which may occur via its effects on agricultural productivity (see channel two above).$^{21}$

Instrumental variable: Finally, there may be a problem of reverse causation to the extent that rural poverty drives rural-migration. It could either act as a push factor (i.e. poorer people migrate in search of an escape out of poverty) or, in the presence of high fixed costs of migration, it may act as a restraint to migration. If the former case prevails (i.e. poverty is mainly a push factor), the coefficient $\beta_{1}$ in (5) would have a downward biased; while the opposite is true if the latter effect of poverty on migration dominates. The findings by Ravallion et al (2007) that global rural-urban migration has been associated with large reduction in the number of rural poor lends some credit to the importance of the former case. Kochar (2004) also provides indirect support to this hypothesis, showing that in India landless households have the highest incidence of rural-urban migrants among rural households. ${ }^{22}$

Regardless of the direction of the bias, we need an additional variable to act as a valid instrument, i.e. it must be correlated with district urban population, but must also be exogenous to poverty-induced rural-urban migration flows. A variable which satisfies both prerequisites is the number of people who migrate to urban areas of the district from states other than the one where the district is located. It is plausible to assume that rural poverty in a given district has no effect on migration decisions in other states, which typically do not share the same rural condition of the district in question. On the other hand, the number of migrants coming to district towns from other states is part of the urban population of the district, thus bearing a positive association with our main explanatory variable. Although measurement error is not likely to be a major cause of concern in our analysis, it is worth noticing that the IV estimation may also correct eventual biases arising from errors in the measurement of urban population. This is the case if the measurement error of the instrument and that of the instrumented variable are independent.

\footnotetext{
${ }^{21}$ Data on agricultural production is not available for all the districts. The inclusion of this variable implies a reduction of the sample to 275 districts.

${ }^{22}$ His finding emerges in the context of the response of rural schooling decisions to the possibility of employment in urban areas, which tends to be larges amongst landless households.
} 


\section{Results}

Table 2 presents the results from regression (5) using OLS estimation. Our dataset includes observations of 363 districts for three different time periods: 1983, 1993, and 1999. We run (5) applying a two years lag to the measure of urban population and to the other demographic controls for two main reasons. First, in this way we reduce the risk of potential simultaneity bias. Second, the two-year lag allows us to minimise the use of interpolation for obtaining the Census variables (both population and socio-demographic variables), which are recorded in 1981, 1991 and $2001 .{ }^{23}$ We also include district and state-year fixed effects in all specifications. Standard errors are robust to heteroscedasticity (using the Huber-White correction) and allow for intra-group correlation within individual observations. ${ }^{24}$

\subsection{3-1999 period}

We run a number of different specifications in Table 2, testing the robustness of the results to the inclusion of a number of controls and the use of different dependent variables. When controlling only for rural population (as well as for the range of fixed effects described above), the result indicates that the growth of urban population exerts a highly significant poverty reducing effect on rural areas (column 1). This result is robust to the inclusion of socio-demographic controls for the rural population, including the share of scheduled caste, the share of young adults (15-34 age group) in the rural population and the share of literates in the young-adults rural population (column 2). ${ }^{25}$ These last two variables are meant to capture a change in the composition of the rural population and therefore should partly absorb the first round effects of urbanization on rural poverty. The inclusion of these controls slightly decreases the urban population coefficient. The signs of the controls are as expected, except for the share of literates: a higher share of young adults decreases poverty, while a higher presence of scheduled caste increases it (although not significantly). This suggests that the direct effect on poverty of the young adult population prevails over their indirect effect which captures the rural-urban migration of young adults. The share of literates has a povertyincreasing, albeit not significant, effect. At a closer inspection, this unexpected effect of

\footnotetext{
${ }^{23}$ In any instance the results are not sensitive to the change in the time lag, i.e. applying a 1 and 0 year lags (results available upon request).

${ }^{24}$ Note that the main results are robust to more basic computations of the standard errors as well.

${ }^{25} \mathrm{We}$ tried to include the share of scheduled tribes in rural population as well, but that is never significant in the different specifications we tried. As this variable is systematically less significant than the scheduled caste variable, we only include the latter as a control.
} 
literacy is driven by its Post-1993 impact. As shown in column 3, the coefficient of this variable turns negative (but not significant) when we account for the significant poverty increasing impact of literacy in the post-1993 period. In this period a higher incidence of literates in the most productive part of the rural labour force was associated with higher levels of rural poverty. Understanding the rationale of such an unexpected result is beyond the scope of our analysis, but we will suggest a possible reason for this below. Accounting for this differential impact determines also an increase in the urban population coefficient, as its effect is probably estimated with more precision. This coefficient is slightly above that of column 1 , suggesting that rural socio-demographics may be capturing some first-round impact of urbanisation, which in this case increases rural poverty. As discussed above, this would be the case if a high level of urbanization was fuelled by high intra-district migration rates. Considering that young adults are over-represented in the migrant population, and that this is the most productive (and thus least poor) part of the population, there may a positive association between urbanization and poverty via this type of first-round effects. The rest of the direct effects of urbanization on rural poverty should be captured by the inclusion of urban poverty rate as a control. This is significantly and positively correlated with rural poverty (column 4). As urban poverty captures both the effects of district's economic growth $(\pi t)$ on rural poverty and the direct effects of urbanisation on rural poverty, this suggests that the former are larger than the latter i.e. $\left|\partial H_{t}^{U} / \partial \pi_{t}\right|>\left|\left(\partial H_{t}^{U} / \partial \sigma\right)+\left(\partial H_{t}^{U} / \partial \gamma\right)\right|$ in (6). The inclusion of urban poverty reduces the urban population coefficient, confirming that the rural poor tend to be over-represented in the migrant population. However this reduction is very mild: the coefficient goes down from -0.0066 to -0.0061 (column 3 to column 4 ) ${ }^{26}$ Following the discussion in the preceding section, we interpret this as a clear indication that most of the effect of urbanization on rural poverty is given by "second-round" mechanisms.

Although robust, the magnitude of the effects of urban population on rural poverty over the 1981-1999 period is not particularly strong. An increase in the district's urban population of 200,000 (a 43\% increase from the mean value) reduces on average the poverty rate by 1 to 1.4 percentage points according to the specifications. Given that the average share of rural poverty over the period considered is $32 \%$, this effect ranges between $3.2 \%$ and $4.2 \%$ of the mean poverty rate.

\footnotetext{
${ }^{26}$ Note that this reduction is in no way attributable to the slight change in the sample's composition from 363 to 354 districts, as confirmed by running the same regression as in column 3 on the same observations as those of column 4 (results available upon request).
} 
Results using the poverty gap index as the dependent variable are less robust than those using the poverty rate (columns 5 and 6). Urban population exerts a negative but mildly significant effect on the poverty gap with the other controls keeping the same sign as in the preceding regressions. This result appears to be driven by the effects of urbanisation on those poor who are relatively close to the poverty line. When the rural poverty share is included among the explanatory variables, the urban population has a positive albeit not significant effect on the poverty gap (column 6), which suggests that the poor closer to the poverty line are those who benefit most from urbanisation. This category does not include those poor far behind the poverty line. In the absence of more precise data, we could only speculate about why this may be the case. The effects of urbanisation are not likely to concern the very poor much. For example, the increase in demand for agricultural goods may affect those involved in commercial agriculture, specifically those who own capital and/or certain skills not usually available to the very poor. The same can be said about rural-urban migration: the very poor may not have enough capital to cover the fixed costs of migration. For these reasons urbanisation seems to have a fairly neutral effect on the very poor rural dwellers. Interestingly, the presence of rural dwellers from the scheduled caste is negatively associated with severe poverty. Along with the results from the preceding regressions, this suggests that the scheduled caste population tends to be concentrated among the rural poor close to the poverty line, but not among those in severe poverty.

We also test for the effects of urbanisation on the number of rural poor (column 7), obtaining similar results. For every increase in urban population by 100 people the rural population in poverty decreases by 13 people. The other controls are in numbers rather than in shares (except for scheduled caste). Following the discussion in section 4, this represents a different way of controlling for the first round effect of urbanisation on rural poverty. In this way, the urban population variable may capture some of the effects of changes in the remaining rural population (net of the young adult population). The controls maintain the same sign as in the previous regressions, except for the rural population, which is now positive and significant and literates in the 15-34 year group, which is now negative and significant. The former result is expected as, other things being equal, a larger rural population is associated with more rural poor. The latter captures the direct association between literacy and poverty, which is negative. This may differ from the preceding 
regressions using shares because those may capture second-order effects of literacy on poverty. $^{27}$

\subsection{3-1993 period}

We now examine the impact of urbanisation on rural poverty using only the first two time periods available, covering the time interval 1981-1993. This is a robustness check for our results with three time periods, as in this case no interpolation of urban population is needed. It is also an interesting analysis focusing only on the pre-liberalisation period. Overall, the effect of urbanisation on rural poverty is stronger than over the entire period (Table 3). The coefficient for the urban population ranges between -0.008 and -0.011 depending on the specification; this is almost twice as large as the range reported in Table 2. An increase in the district's urban population of 200,000 reduces on average the poverty rate by between 1.6 and $2.2 \%$ of total rural population. The basic specification without controls (except for the fixed effects) confirms the negative relationship between urbanisation and rural poverty, although it is only mildly significant (column 1). The inclusion of sociodemographic controls increases the significance and the size of the coefficient, again confirming that some adverse first-round impacts of urbanisation on rural poverty are taken away by these controls (column 2). Both the share of young adults in the rural population and the share of literature in the young adult share exert a poverty-reducing impact. This supports the hypothesis of a differential impact of literacy on rural poverty over time, i.e. povertyreducing up to 1993 and then poverty-increasing. The results are robust to the addition of the share of urban poverty (column 4). However, this time the magnitude of the coefficient of urban population increases from 0.0099 (column 3, which uses the same sample as in column 4) to 0.0110 . This increase suggests that the first-round effects of urbanisation on rural poverty captured by urban poverty may have been poverty-increasing in the eighties. Again this is a very small change, confirming that second-round effects are likely to dominate firstround ones. The impact of urbanisation on the poverty gap index is negative but less significant than for the entire period (column 5), while the impact on severe poverty seems to be neutral again. Finally, the results also hold when using the number of rural poor as a dependent variable (column 6). Again, the elasticity of poverty reduction is much higher than that considered in the 1981-1999 period.

\footnotetext{
${ }^{27}$ When we control for the number (instead of the share) of urban poor to better control for first-round effects of urbanisation on rural poverty, the elasticity of reduction in rural poor is slightly lower (results available upon request).
} 


\subsection{Further robustness}

To control for eventual endogeneity due to the potential effects of agricultural productivity on urbanisation, we add a measure of agricultural productivity to the list of controls. This variable is lagged one year, given that the simultaneity bias should not be an issue in this case (but a contemporaneous specification is not possible due to the lack of data for 1999). The main results reported in Table 4 appear to be robust to the inclusion of such a measure. Surprisingly, the urban population coefficient for the entire period increases (column 1). However, this effect is mainly due to the restricted sample for which agricultural data is available. When we run the same regression as in Table 2 column 4 with the same sample as in Table 4 column 1, the increase in the size of the urban coefficient disappears (column 2). To the extent that part of the poverty-reducing effects of urbanisation may operate through increases in agricultural productivity (see section 2 above), the unchanged urbanisation coefficient is a somewhat puzzling result. The key to explain this may be the surprisingly weak (negative) effect of agricultural productivity on rural poverty (column 2). If this is the case, then the effects of urbanisation via productivity increases would be fairly insignificant as well. In fact, when restricting the analysis to the 1983-93 period, the coefficient of agricultural productivity becomes negative (as expected) and the magnitude of the urbanisation impact on rural poverty decreases slightly, although it maintains its significance (column 3 vs. column 4). This suggests that agricultural productivity may have had a different impact on rural poverty in the post-1993 period. Column 5 confirms such a hypothesis, as the post-1993 effect of productivity appears to have been robustly adverse to rural poverty. Such a surprising finding may be in contradiction with earlier literature on India, which shows the key effect of higher farm yield in poverty reduction only until 1994 (Datt and Ravallion, 1998). ${ }^{28}$ Investigating the reasons behind this adverse post-1993 impact is beyond the scope of our analysis, and we only speculate about a possible explanation for it. This may lie in the (negative) effect of agricultural productivity on rural employment in the non-farm tradable sector (e.g. rural industry). Foster and Rosenzweig (2004) find this pattern for Indian villages and explain it through the negative incentives that agricultural productivity growth provides to capital in the non-farm tradable sector through higher wages. To the extent

\footnotetext{
${ }^{28}$ However, our result may appear to be at odds with recent work by Eswaran et al. (2008), finding that increases in agricultural productivity explain most of the rise in agricultural wages in the 1983-1999 period. The contradiction may be more apparent than real due to substantial methodological differences. First, Eswaran et al. use agricultural wages as an indicator of poverty; second, they perform the analysis on the whole economy without distinguishing between the rural and urban sector; finally, they do not use econometric techniques to estimate the impact of the agricultural productivity on agricultural wages.
} 
that non-farm growth is especially pro-poor (as rural industry tends to productively employ the main asset of poor rural households, i.e. low-skilled labour), this negative effect on nonfarm growth may dampen that of agricultural productivity growth on rural poverty. This effect may have been particularly strong in the post-liberalisation period (i.e. post-1991), when labour was freer to move in search for lower-wage locations (see Aghion et al., 2007). Incidentally, the same argument may also help explain the adverse impact of literacy on rural poverty in the nineties. Since literate labour has a higher reservation wage than illiterate labour, a high share of literate labour may have acted as a restraint to investments by the nonfarm tradable sector.

We already mentioned that to the extent that rural-urban migration occurs across districts, the identification strategy may not enable us to properly capture the channels linking urbanisation to rural poverty. In order to control for this, we need to construct a variable that measures the weight of rural-urban intra-district migration in the total rural emigrant population. By connecting this variable to the urban population, we may control for the fact that the effects of urbanisation on rural poverty are better identified in those districts with a relatively higher share of internal rural-urban migration in total rural emigrants. However, the data available does not allow us to compute such a share; we instead compute a rough approximation of this measure by dividing intra-district rural-urban migration by rural population. Including the interaction between this variable and the urban population leaves the results unaffected (column 6) with the interaction term bearing an expected but insignificant negative coefficient. We also use a different variable, i.e. the ratio of intradistrict rural-urban migrants over the urban immigrants from other districts, obtaining similar (negative and non significant) results (not shown here). The lack of significance of these results may be due to the imprecise measure of the importance of intra-district migration.

Finally, we test for the importance of the backward linkage effects of urbanisation on poverty. Considering that urban agricultural demand affects the district's rural sector more intensely in less spatially integrated markets, we need information on the share of urban demand of perishable products in total urban demand. Since we do not have this information, we instead compute a rough approximation based on agricultural data: the share of land cultivated fruits and vegetables (proxy for perishable goods) in total land cultivated. This measure relies on a number of assumptions, i.e. that a district's supply is a good proxy for urban demand and that fruits and vegetables are the main perishable agricultural goods. The interaction term between this share and the urban population variable has an expected negative coefficient (i.e. the higher the share the more poverty-reducing the urbanisation 
impact) - column 7. Again, this is not significant due to the imprecision of the measure. Also, including this interaction term reduces the explanatory power and the significance of the urbanisation variable. This may be due to the high collinearity between the two variables generated by the small variation of the fruit and vegetable share over time.

Given that limiting the spatial extent of the effect of urbanization within the border of single districts may be questionable, we run the same specifications of tables 2-4 adding a spatially lagged urbanization variable, i.e., the average of the urban population of the contiguous districts. ${ }^{29} \mathrm{We}$ also try to include the spatial lag of total population. These variables however were never significant, while other coefficients were only minimally affected (table 5, first column).

Finally, a further bias may be due to small villages upgrading to towns in the census definition. To the extent that these growing villages are systematically located in rural areas where poverty is decreasing (increasing) for reasons independent of urbanisation, we may detect a negative (positive) effect of urban population on poverty share which would be spurious. We therefore re-estimate the models excluding from the urban population variable towns with less than 20,000 inhabitants - i.e., the size category which would contain most of the 'upgraded villages'. Results of this regression are extremely similar, although slightly less precise (see Table 5, second column).

\subsection{IV estimation}

Although the results are neat, we still need to control for the direction of causality in the relationship between urbanisation and rural poverty. As rural poverty declines (increases), the rural-urban migration rate and thus urbanization may slow down (rise) as well. This would provide a source of (downward) bias in the coefficient. Without properly controlling for this potential endogeneity, the coefficient of equation (5) may have a downward biased, which means the estimates in Table 1 may be lower in absolute value than the real ones. ${ }^{30}$

We resort to Instrumental Variable estimation (two stages least squares) to deal with this problem, using the number of migrants from other states to the urban areas of the district as an instrument. The first stage regressions, reported in different specifications in Table 6,

\footnotetext{
${ }^{29}$ Technically, the variable is equal to $\mathrm{Wx}$, where $\mathrm{W}$ is a row-standardized queen contiguity matrix, and $\mathrm{x}$ is the vector of urban population of districts.

${ }^{30}$ This is subject to the caveats that the sign of the bias in a multivariate regression depends also on the correlation with other regressors; and that the direction of the reverse causality may also be the opposite if poverty is a constraint to migration rather than a push factor.
} 
substantiate the strong correlation of the instrument with the instrumented variable, and Fstatistics are well above the confidence threshold of Stock and Yogo (2005) test for weak instruments (Table 6-7, last row). In analogy with OLS, IV estimations' standard errors are robust and allow for intra-group correlation at district level. ${ }^{31}$

Results from the second stage regressions confirm the suspect of a downward bias of the OLS parameters, with new estimates being roughly twice as large as the OLS estimation for the period 1981-1999 (Table 7). This in turn implies a fairly substantial impact of urbanisation on rural poverty, with the rural poor decreasing by between $2 \%$ and $3 \%$ of districts' rural populations as the effect of an increase by 200,000 in urban residents (columns 1-3). The IV analysis confirms the small first-round relative to second-round effects of urbanisation on rural poverty (column 1 to 2). Again, the results are robust when agricultural productivity variables are included as a control. We also run the IV estimation using the poverty gap as a dependent variable. The change in the magnitude of the urban coefficients compared to the OLS specification in Table 2 is even bigger, and it maintains its significance (column 4). Again, when the share of rural poor is included as a control, the coefficient of urban population loses its significance and becomes positive (column 4). This confirms that urbanisation does not have an independent effect on the poverty gap, and thus on the severity of poverty, other than through the effect induced by the decrease in the share of poor in the rural population. The increase in magnitude of the coefficient is confirmed even when using the absolute number of rural poor as a dependent variable, although the coefficient is only 1.5 larger in this case (column 6).

We also run the same regressions for the first two periods, obtaining similar results. The coefficient of urban population is magnified by a factor of between 3 and 5 relative to its OLS value, although it is estimated fairly imprecisely in the specifications with few control variables. This is also true for the specification using the poverty gap as a dependent variable (column 4), although the inclusion of the share of rural poor as a control eliminates any effect on the urban population. This is also the case for the estimation run with the number of rural poor as a dependent variable: the increase of the urban coefficient is 4 -fold. The robustness checks examined in the previous paragraph, including the spatially lagged variable and the

\footnotetext{
${ }^{31}$ In order to get the covariance matrix of orthogonality conditions of full rank, which in turn allows to calculate clustered s.e., year-state dummies are "partialled out" and their coefficient is not calculated. By the FrischWaugh-Lovell theorem, in IV the coefficients for the remaining regressors are the same as those that would be obtained if the variables were not partialled out (Baum et al, 2008).
} 
population of towns with more than 20,000 inhabitants, do not affect our results when applied to the IV setting (table 5, columns 3 and 4).

Finally, the substantial downward bias of the OLS estimates implied by the IV results suggests that an increase in poverty may be an important push factor for rural-urban migration. This could indicate that the poverty incidence is higher among migrants than among non-migrants (thus $\sigma>\gamma$ ). At the same time, our results suggest that first-round effects are quite small, i.e. condition (3) $[\sigma>\gamma+(\varphi-\lambda)]$ does not hold in its strong form. This would imply, consistently with the discussion in section 2 , that the poverty incidence is lower in rural areas that are about to become urban than in the other rural areas (thus $\lambda<\varphi$ ), and interestingly this difference is similar to that of poverty rates between rural-urban migrants and rural non-migrants, i.e. $[(\sigma-\gamma) \approx(\varphi-\lambda)]$. Obviously the evidence provided here is not strong enough to make this more than an interesting speculation. And further research would be necessary to provide more direct empirical testing of such a hypothesis.

\section{Conclusions}

Do the poor in rural areas benefit from population growth of urban areas? And if so, what is the size of the benefits? Answers to these questions could help clarify whether tradeoffs exist between urban investment and rural poverty and may help shed new light on the old debate on urban bias in developing countries. Notwithstanding the importance of these questions, little empirical evidence is available to provide adequate answers. We have tried to address this gap, by analysing the effects of urbanization on rural poverty. Using data on Indian districts between 1981 and 1999, we find that urbanization has a significantly poverty reducing effect on surrounding rural areas. Results are robust to the inclusion of a number of controls and to the use of different types of specification. The findings suggest that most of the poverty reducing impact of urbanization occurs through second-round effects rather than through the direct movement of rural poor to urban areas. We resort to IV estimation to test for causality. The results suggest that the effect is causal (from urbanisation to poverty reduction), and that failure to control for causality bias the coefficient of urbanisation downwardly. In our preferred estimations, we find that an increase of urban population by one fifth determines a decrease of between 3 and 6 percentage points in the share of rural poverty. These poverty reducing effects appear to apply mostly to rural poor relatively closer to the 
poverty line. Although the very poor do not seem to be negatively affected by urbanization, they are not able to reap the benefits of such a growth.

These findings may bear a number of potentially important policy implications. First, they may help re-consider the role of public investment in urban areas for poverty reduction. In fact it is a popular tenet that investments in developing countries need to be concentrated in rural areas in order to reduce poverty, as the poor in developing countries are mainly concentrated there (see for instance World Bank, 2008). However, investments in rural areas are often very onerous as substantial resources are needed to reach a population which is scattered around vast territories. To the extent that urbanization may have substantial poverty reducing effects on rural areas, urban investments may become an important complement to rural ones in poverty reduction strategies.

Second, our findings run counter the popular myth that rural-urban migration may deplete rural areas causing them to fall further behind. The relatively low rate of urbanisation of India itself may also be due to public policies which have not facilitated (and in certain instance even constrained) rural-urban migration (Deshingkar and Start, 2005). At the very least, this paper questions the appropriateness of this bias against rural-urban migration.

Third, to the extent that the benefits from urbanisation do not spill over to the very poor in rural areas, specific actions may be needed to facilitate these rural dwellers to enjoy the benefits of urbanisation. Examples of these may include developing the types of skills useful for an expanding urban sector; or the provision of capital to cover the fixed costs of rural-urban migration.

Although this paper has not touched upon the issue of urban poverty, rising urban populations may imply that urban poverty could become in the future the main issue in its own right (Ravallion et al., 2007). Further research is needed to assess whether the growth of urban population entails a trade-off between rural and urban poverty reduction. 


\section{Figures and Tables}

Table 2: The effects of urbanization on rural poverty across Indian districts, 1983-1999

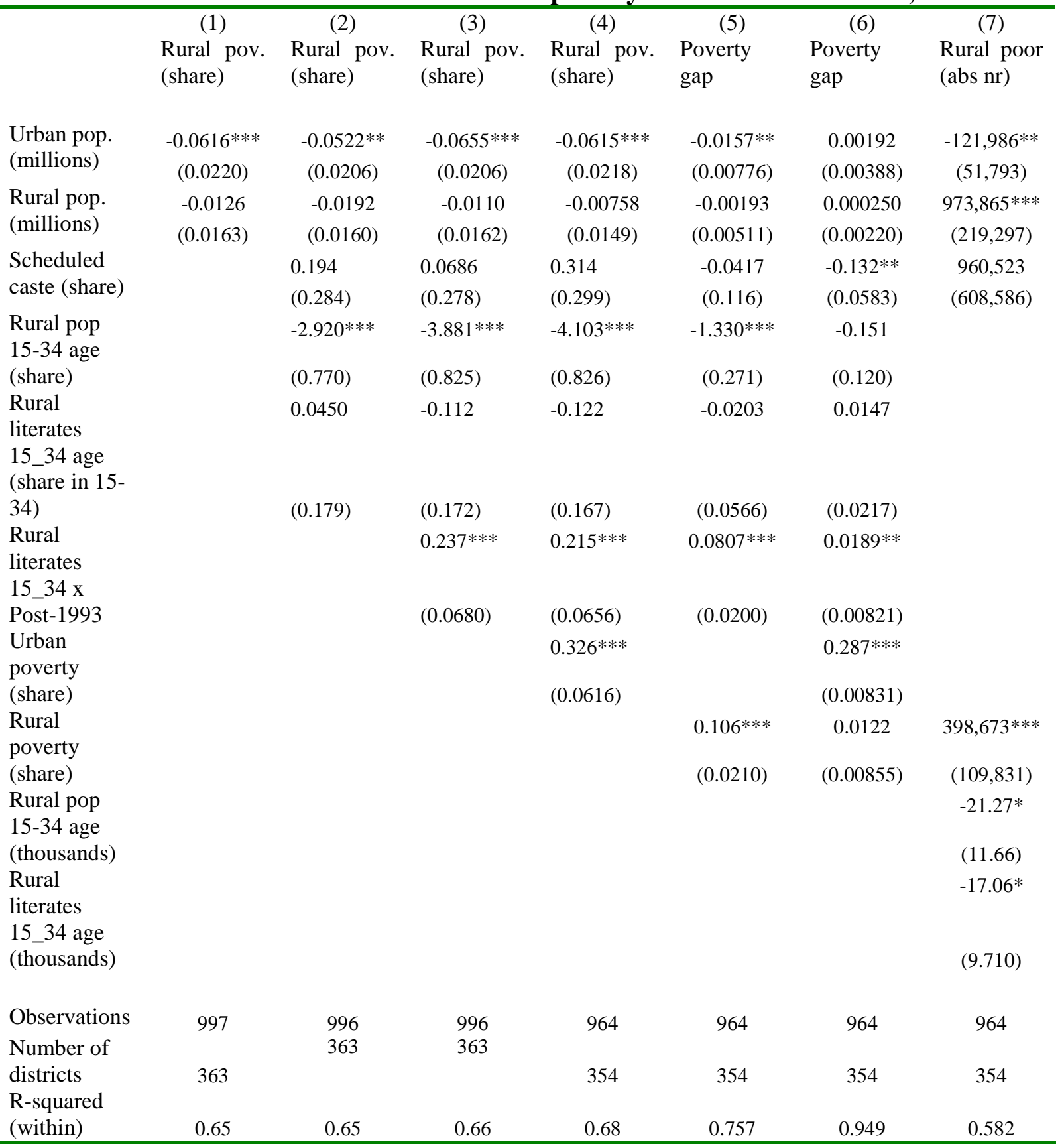

\footnotetext{
All specifications include district and state-year fixed effects. Robust t-statistics in parenthesis; ***p<0.01, ** $p<0.05, * p<0.1 ;$ all
} explanatory variables are lagged two years except for Agricultural Productivity (1 year lag) and urban poverty (contemporaneous) 
Table 3: The effects of urbanization on rural poverty across Indian districts, 1983-1993, OLS

\begin{tabular}{|c|c|c|c|c|c|c|}
\hline & $\begin{array}{c}\text { (1) } \\
\text { Rural pov. } \\
\text { (share) }\end{array}$ & $\begin{array}{c}\text { (2) } \\
\text { Rural pov. } \\
\text { (share) }\end{array}$ & $\begin{array}{c}\text { (3) } \\
\text { Rural pov. } \\
\text { (share) }\end{array}$ & $\begin{array}{c}(4) \\
\text { Poverty } \\
\text { gap }\end{array}$ & $\begin{array}{c}(5) \\
\text { Poverty } \\
\text { gap }\end{array}$ & $\begin{array}{c}\text { (6) } \\
\text { Rural poor } \\
\text { (millions) }\end{array}$ \\
\hline $\begin{array}{l}\text { Urban pop. } \\
\text { (millions) }\end{array}$ & $\begin{array}{l}-0.0791 \\
(0.0592)\end{array}$ & $\begin{array}{l}-0.0928 * \\
(0.0553)\end{array}$ & $\begin{array}{l}-0.111 * * \\
(0.0549)\end{array}$ & $\begin{array}{l}-0.0265 \\
(0.0168)\end{array}$ & $\begin{array}{c}0.00549 \\
(0.00809)\end{array}$ & $\begin{array}{l}-281415^{* *} \\
(111438)\end{array}$ \\
\hline $\begin{array}{l}\text { Rural pop. } \\
\text { (millions) }\end{array}$ & $\begin{array}{l}-0.0791 \\
(0.0592)\end{array}$ & $\begin{array}{l}-0.0928 * \\
(0.0553)\end{array}$ & $\begin{array}{l}-0.111 * * \\
(0.0549)\end{array}$ & $\begin{array}{l}-0.0265 \\
(0.0168)\end{array}$ & $\begin{array}{c}0.00549 \\
(0.00809)\end{array}$ & $\begin{array}{l}-281415^{* * *} \\
(111438)\end{array}$ \\
\hline $\begin{array}{l}\text { Scheduled caste } \\
\text { (share) }\end{array}$ & & $\begin{array}{l}0.0691 \\
(0.398)\end{array}$ & $\begin{array}{c}0.383 \\
(0.505)\end{array}$ & $\begin{array}{c}-0.00927 \\
(0.207)\end{array}$ & $\begin{array}{l}-0.120 \\
(0.114)\end{array}$ & $\begin{array}{c}817119 \\
(1.01 \mathrm{e}+06)\end{array}$ \\
\hline $\begin{array}{l}\text { Rural pop } 15-34 \\
\text { age (share) }\end{array}$ & & $\begin{array}{c}-4.619 * * * \\
(1.306)\end{array}$ & $\begin{array}{c}-5.313 * * * \\
(1.408)\end{array}$ & $\begin{array}{c}-1.739 * * * \\
(0.473)\end{array}$ & $\begin{array}{l}-0.207 \\
(0.224)\end{array}$ & \\
\hline $\begin{array}{l}\text { Rur. literates } \\
\text { (share in 15-34) }\end{array}$ & & $\begin{array}{c}-0.700 * * * \\
(0.216)\end{array}$ & $\begin{array}{c}-0.835^{* * *} \\
(0.255)\end{array}$ & $\begin{array}{l}-0.179 * * \\
(0.0845)\end{array}$ & $\begin{array}{c}0.0620 \\
(0.0408)\end{array}$ & \\
\hline $\begin{array}{l}\text { Urban poverty } \\
\text { (share) }\end{array}$ & & & $\begin{array}{c}0.378 * * * \\
(0.106)\end{array}$ & $\begin{array}{l}0.140 * * * \\
(0.0396)\end{array}$ & $\begin{array}{c}0.0310 \\
(0.0233)\end{array}$ & $\begin{array}{c}483853 * * * \\
(186673)\end{array}$ \\
\hline $\begin{array}{l}\text { Rural poverty } \\
\text { (share) }\end{array}$ & & & & & $\begin{array}{l}0.288 * * * \\
(0.0116)\end{array}$ & \\
\hline $\begin{array}{l}\text { Rural pop } 15-34 \\
\text { age }(x 100,000)\end{array}$ & & & & & & $\begin{array}{l}-12.02 \\
(21.52)\end{array}$ \\
\hline $\begin{array}{l}\text { Rural lit. 15_34 } \\
\text { age (x100,000) }\end{array}$ & & & & & & $\begin{array}{c}-42.45^{* * * *} \\
(11.19)\end{array}$ \\
\hline Observations & 682 & 682 & 659 & 659 & 659 & 659 \\
\hline No. of districts & 363 & 363 & 354 & 354 & 354 & 354 \\
\hline R-sq. (within) & 0.611 & 0.640 & 0.660 & 0.763 & 0.940 & 0.589 \\
\hline
\end{tabular}


Table 4: The effects of urbanization on rural poverty across Indian districts, Further robustness

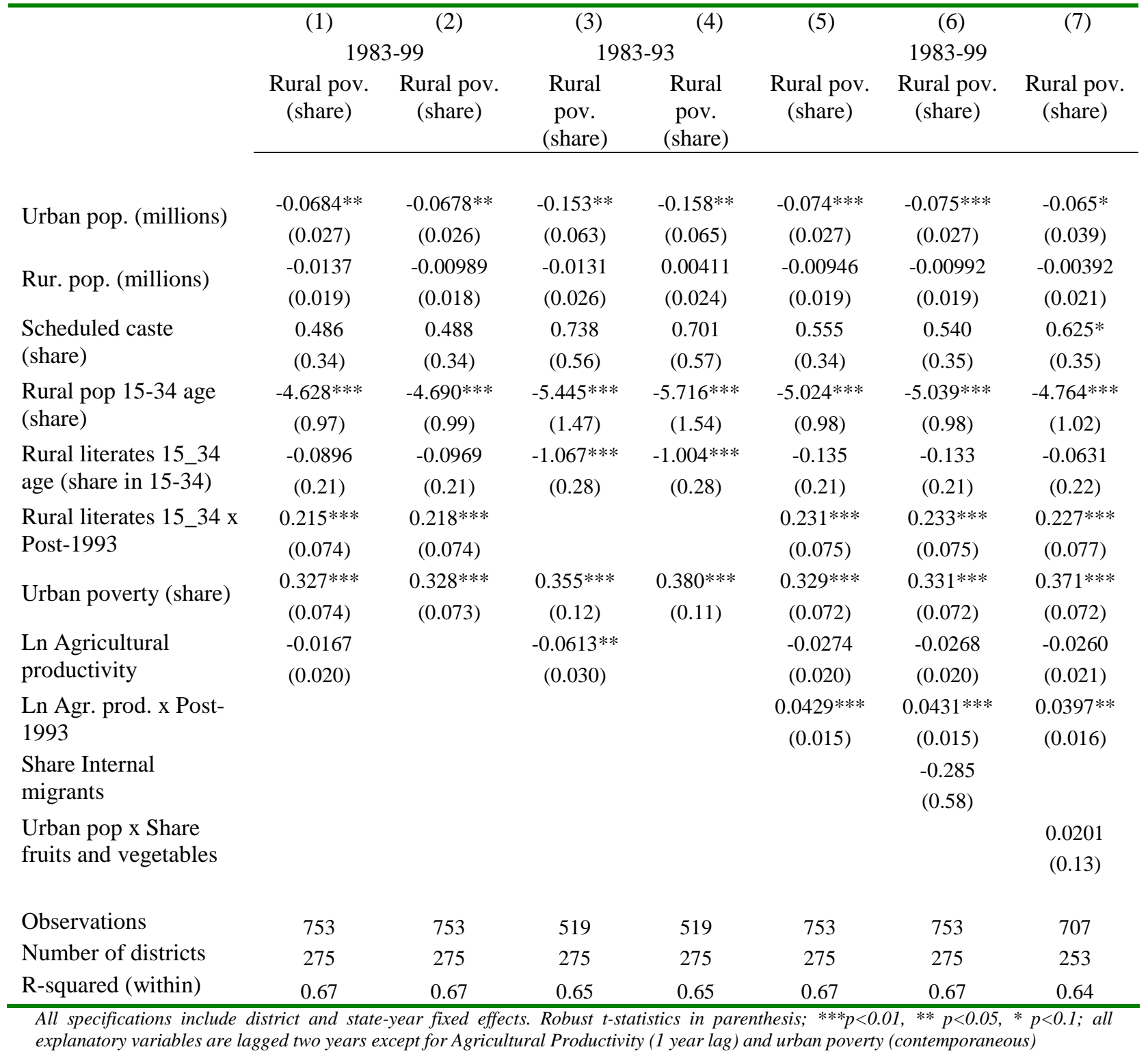


Table 5: The effects of urbanization on rural poverty across Indian districts, further robustness

\begin{tabular}{|c|c|c|c|c|}
\hline \multirow{3}{*}{ Sample } & (1) & (2) & (3) & (4) \\
\hline & All & Cities $>20 \mathrm{k}$ & All & Cities $>20 \mathrm{k}$ \\
\hline & Rural pov. (share) & Rural pov. (share) & Rural pov. (share) & Rural pov. (share) \\
\hline \multirow{2}{*}{ Urban pop. (millions) } & $-0.0496 * *$ & -0.0365 & $-0.108 * * *$ & $-0.112 * * *$ \\
\hline & $(0.0222)$ & $(0.0231)$ & $(0.0377)$ & $(0.0408)$ \\
\hline \multirow{2}{*}{$\begin{array}{l}\text { Urban pop. of bordering } \\
\text { districts (millions) }\end{array}$} & $1.67 \mathrm{e}-07$ & & $2.96 \mathrm{e}-07$ & \\
\hline & $(5.79 \mathrm{e}-07)$ & & $(5.97 \mathrm{e}-07)$ & \\
\hline \multirow{2}{*}{ Rural pop. (millions) } & -0.0155 & -0.00851 & -0.0132 & -0.00348 \\
\hline & $(0.0146)$ & $(0.0145)$ & $(0.0146)$ & $(0.0146)$ \\
\hline \multirow{2}{*}{ Urban poverty (share) } & $0.326 * * *$ & $0.326 * * *$ & $0.322 * * *$ & $0.323 * * *$ \\
\hline & $(0.0637)$ & $(0.0626)$ & $(0.0629)$ & $(0.0621)$ \\
\hline \multirow{2}{*}{ Scheduled caste (share) } & 0.474 & 0.372 & 0.483 & 0.325 \\
\hline & $(0.301)$ & $(0.293)$ & $(0.301)$ & $(0.298)$ \\
\hline \multirow{2}{*}{$\begin{array}{l}\text { Rural literates } 15 \_34 \text { age } \\
\text { (share in } 15-34)\end{array}$} & $-3.329 * * *$ & $-3.181 * * *$ & $-3.262 * * *$ & $-3.039 * * *$ \\
\hline & $(0.769)$ & $(0.820)$ & $(0.739)$ & $(0.787)$ \\
\hline \multirow{2}{*}{$\begin{array}{l}\text { Rural literates } 15 \_34 \text { age } \\
\text { (share in } 15-34 \text { ) }\end{array}$} & 0.0253 & -0.118 & 0.00369 & -0.147 \\
\hline & $(0.162)$ & $(0.162)$ & $(0.159)$ & $(0.160)$ \\
\hline Observations & 953 & 952 & 914 & 901 \\
\hline R-squared (within) & 0.678 & 0.682 & & \\
\hline Number of districts & 343 & 354 & 306 & 305 \\
\hline Method & OLS & OLS & IVE & IVE \\
\hline
\end{tabular}

All specifications include district and state-year fixed effects. Robust z-statistics in parenthesis; $* * * p<0.01$, ** $p<0.05, * p<0.1 ;$ urban population is instrumented through the number of urban immigrants from other states. 
Table 6: The effects of urbanization on rural poverty across Indian districts, 1983-1999, IV Estimation

\begin{tabular}{|c|c|c|c|c|c|c|}
\hline & $\begin{array}{l}\text { (1) } \\
\text { Rural pov. } \\
\text { (share) }\end{array}$ & $\begin{array}{l}\text { (2) } \\
\text { Rural pov. } \\
\text { (share) }\end{array}$ & $\begin{array}{l}\text { (3) } \\
\text { Rural pov. } \\
\text { (share) }\end{array}$ & $\begin{array}{c}\text { (4) } \\
\text { Poverty gap }\end{array}$ & $\begin{array}{c}\text { (5) } \\
\text { Poverty gap }\end{array}$ & $\begin{array}{l}\text { (6) } \\
\text { Rural poor } \\
\text { (abs nr) }\end{array}$ \\
\hline Urban pop. (millions) & $\begin{array}{c}-0.112 * * * \\
(0.033)\end{array}$ & $\begin{array}{c}-0.117 * * * \\
(0.034)\end{array}$ & $\begin{array}{c}-0.139 * * * \\
(0.031)\end{array}$ & $\begin{array}{c}-0.0393 * * * \\
(0.012)\end{array}$ & $\begin{array}{l}0.00105 \\
(0.0052)\end{array}$ & $\begin{array}{c}-162433^{* *} \\
(65652)\end{array}$ \\
\hline Rural pop. (millions) & $\begin{array}{c}-0.00770 \\
(0.016)\end{array}$ & $\begin{array}{c}-0.00427 \\
(0.015)\end{array}$ & $\begin{array}{c}0.000761 \\
(0.017)\end{array}$ & $\begin{array}{l}0.00204 \\
(0.0059)\end{array}$ & $\begin{array}{l}0.00182 \\
(0.0025)\end{array}$ & $\begin{array}{c}1.47 \mathrm{e}+06 * * * \\
(254350)\end{array}$ \\
\hline $\begin{array}{l}\text { Scheduled caste } \\
\text { (share) }\end{array}$ & $\begin{array}{c}0.0646 \\
(0.27)\end{array}$ & $\begin{array}{l}0.292 \\
(0.30)\end{array}$ & $\begin{array}{l}0.406 \\
(0.32)\end{array}$ & $\begin{array}{c}-0.0281 \\
(0.12)\end{array}$ & $\begin{array}{c}-0.146 * * \\
(0.058)\end{array}$ & $\begin{array}{c}1.09 \mathrm{e}+06^{*} \\
(649713)\end{array}$ \\
\hline $\begin{array}{l}\text { Rural pop } 15-34 \text { age } \\
\text { (share) }\end{array}$ & $\begin{array}{c}-3.845^{* * *} \\
(0.79)\end{array}$ & $\begin{array}{c}-4.057 * * * \\
(0.79)\end{array}$ & $\begin{array}{c}-4.808 * * * \\
(0.88)\end{array}$ & $\begin{array}{c}-1.573 * * * \\
(0.30)\end{array}$ & $\begin{array}{l}-0.172 \\
(0.14)\end{array}$ & \\
\hline $\begin{array}{l}\text { Rural literates 15_34 } \\
\text { age (share in 15-34) }\end{array}$ & $\begin{array}{l}-0.139 \\
(0.17)\end{array}$ & $\begin{array}{r}-0.153 \\
(0.16)\end{array}$ & $\begin{array}{r}-0.263 \\
(0.20)\end{array}$ & $\begin{array}{l}-0.0702 \\
(0.069)\end{array}$ & $\begin{array}{l}0.00652 \\
(0.027)\end{array}$ & \\
\hline $\begin{array}{l}\text { Rural literates 15_34 } \\
\text { x Post-1993 }\end{array}$ & $\begin{array}{c}0.249 * * * \\
(0.067)\end{array}$ & $\begin{array}{c}0.230 * * * \\
(0.064)\end{array}$ & $\begin{array}{c}0.281 * * * \\
(0.070)\end{array}$ & $\begin{array}{c}0.105 * * * \\
(0.022)\end{array}$ & $\begin{array}{l}0.0231 * * \\
(0.0094)\end{array}$ & \\
\hline $\begin{array}{l}\text { Urban poverty } \\
\text { (share) }\end{array}$ & & $\begin{array}{l}0.323 * * * \\
(0.061)\end{array}$ & $\begin{array}{l}0.338 * * * \\
(0.067)\end{array}$ & $\begin{array}{c}0.116^{* * * *} \\
(0.023)\end{array}$ & $\begin{array}{l}0.0173 * \\
(0.0095)\end{array}$ & $\begin{array}{l}400081 * * * \\
(112358)\end{array}$ \\
\hline Ln Agr. productivity & & & $\begin{array}{l}-0.128 \\
(0.078)\end{array}$ & $\begin{array}{l}-0.0236 \\
(0.021)\end{array}$ & $\begin{array}{l}0.0136 \\
(0.012)\end{array}$ & $\begin{array}{l}-411497 * * * \\
(146218)\end{array}$ \\
\hline $\begin{array}{l}\text { Ln Agr. prod. x Post- } \\
1993\end{array}$ & & & $\begin{array}{c}0.165 * * * \\
(0.062)\end{array}$ & $\begin{array}{l}0.0482 * * * \\
(0.017)\end{array}$ & $\begin{array}{c}-0.0000217 \\
(0.0085)\end{array}$ & $\begin{array}{c}373123 * * * \\
(113748)\end{array}$ \\
\hline Rural poverty (share) & & & & & $\begin{array}{l}0.291 * * * \\
(0.0090)\end{array}$ & \\
\hline $\begin{array}{l}\text { Rural pop } 15-34 \text { age } \\
(x 100,000)\end{array}$ & & & & & & $\begin{array}{c}-36.95 * * * \\
(10.36)\end{array}$ \\
\hline $\begin{array}{l}\text { Rural literates 15_34 } \\
\text { age (millions) }\end{array}$ & & & & & & $\begin{array}{c}-30.68 * * * \\
(10.19)\end{array}$ \\
\hline $\begin{array}{l}\text { Rural lit. } 15 \_34 \text { age } \\
\text { (millions) x post-93 }\end{array}$ & & & & & & $\begin{array}{c}9.128 * * * \\
(2.925)\end{array}$ \\
\hline Observations & 950 & 914 & 753 & 753 & 753 & 753 \\
\hline Number of districts & 319 & 306 & 255 & 255 & 255 & 255 \\
\hline $\begin{array}{l}\text { R-squared } \\
\text { Kleibergen- } \\
\text { Paark Wald F } \\
\text { statistic }\end{array}$ & 27.089 & 0.11 & 0.13 & 0.14 & 0.82 & 0.31 \\
\hline
\end{tabular}

All specifications include district and state-year fixed effects. Robust z-statistics in parenthesis; ***p<0.01, ** $p<0.05, * p<0.1$; urban population is instrumented through the number of urban immigrants from other states. 
Table 7: The effects of urbanization on rural poverty across Indian districts, 1983-1993, IV Estimation

\begin{tabular}{|c|c|c|c|c|c|c|}
\hline & $\begin{array}{c}\text { (1) } \\
\text { Rural pov. } \\
\text { (share) }\end{array}$ & $\begin{array}{c}(2) \\
\text { Rural pov. } \\
\text { (share) }\end{array}$ & $\begin{array}{c}(3) \\
\text { Rural pov. } \\
\text { (share) }\end{array}$ & $\begin{array}{c}\text { (4) } \\
\text { Poverty gap }\end{array}$ & $\begin{array}{c}\text { (5) } \\
\text { Poverty gap }\end{array}$ & $\begin{array}{l}\text { (6) } \\
\text { Rural poor } \\
\text { (abs nr) }\end{array}$ \\
\hline Urban pop. (millions) & $\begin{array}{r}-0.268 \\
(0.20)\end{array}$ & $\begin{array}{l}-0.315 \\
(0.20)\end{array}$ & $\begin{array}{c}-0.506 * * \\
(0.21)\end{array}$ & $\begin{array}{c}-0.147 * * \\
(0.058)\end{array}$ & $\begin{array}{l}0.00143 \\
(0.0157)\end{array}$ & $\begin{array}{l}-843141 * * \\
(371035)\end{array}$ \\
\hline Rural pop. (millions) & $\begin{array}{l}0.000299 \\
(0.0024)\end{array}$ & $\begin{array}{l}0.00111 \\
(0.0024)\end{array}$ & $\begin{array}{l}0.00248 \\
(0.0031)\end{array}$ & $\begin{array}{l}0.000471 \\
(0.0011)\end{array}$ & $\begin{array}{l}-0.00256 \\
(0.00432)\end{array}$ & $\begin{array}{c}725858 \\
(513498)\end{array}$ \\
\hline Scheduled caste (share) & $\begin{array}{l}0.174 \\
(0.44)\end{array}$ & $\begin{array}{l}0.556 \\
(0.56)\end{array}$ & $\begin{array}{l}0.877 \\
(0.67)\end{array}$ & $\begin{array}{l}0.133 \\
(0.26)\end{array}$ & $\begin{array}{l}-0.125 \\
(0.122)\end{array}$ & $\begin{array}{c}1.10 \mathrm{e}+06 \\
(1.32 \mathrm{e}+06)\end{array}$ \\
\hline $\begin{array}{l}\text { Rural pop } 15-34 \text { age } \\
\text { (share) }\end{array}$ & $\begin{array}{c}-4.754 * * * \\
(1.31)\end{array}$ & $\begin{array}{c}-5.535 * * * \\
(1.41)\end{array}$ & $\begin{array}{c}-5.628 * * * \\
(1.52)\end{array}$ & $\begin{array}{c}-1.889 * * * \\
(0.55)\end{array}$ & $\begin{array}{l}-0.237 \\
(0.259)\end{array}$ & \\
\hline $\begin{array}{l}\text { Rural literates } 15 \_34 \text { age } \\
\text { (share in } 15-34 \text { ) }\end{array}$ & $\begin{array}{c}-0.738 * * * \\
(0.21)\end{array}$ & $\begin{array}{c}-0.867 * * * \\
(0.25)\end{array}$ & $\begin{array}{c}-1.073 * * * \\
(0.29)\end{array}$ & $\begin{array}{c}-0.257 * * \\
(0.10)\end{array}$ & $\begin{array}{c}0.0582 \\
(0.0460)\end{array}$ & \\
\hline Urban poverty (share) & & $\begin{array}{c}0.390 * * * \\
(0.11)\end{array}$ & $\begin{array}{c}0.400 * * * \\
(0.12)\end{array}$ & $\begin{array}{c}0.164 * * * \\
(0.046)\end{array}$ & $\begin{array}{l}0.0465 * \\
(0.0260)\end{array}$ & $\begin{array}{l}508135 * * \\
(200560)\end{array}$ \\
\hline Ln Agr. productivity & & & $\begin{array}{l}-0.0984 \\
(0.078)\end{array}$ & $\begin{array}{l}-0.0163 \\
(0.024)\end{array}$ & $\begin{array}{c}0.0126 \\
(0.0134)\end{array}$ & $\begin{array}{c}-378169 * * \\
(149379)\end{array}$ \\
\hline Rural poverty (share) & & & & & $\begin{array}{l}0.294 * * * \\
(0.0132)\end{array}$ & \\
\hline $\begin{array}{l}\text { Rural pop } 15-34 \text { age } \\
\text { (millions) }\end{array}$ & & & & & & $\begin{array}{c}7.514 \\
(24.18)\end{array}$ \\
\hline $\begin{array}{l}\text { Rural literates 15_34 age } \\
\text { (millions) }\end{array}$ & & & & & & $\begin{array}{c}-49.73 * * * \\
(11.41)\end{array}$ \\
\hline Observations & 636 & 608 & 488 & 488 & 488 & 488 \\
\hline Number of districts & 318 & 304 & 244 & 244 & 244 & 244 \\
\hline $\begin{array}{l}\text { R-squared } \\
\text { Kleibergen- }\end{array}$ & 0.06 & 0.10 & 0.04 & 0.03 & 0.823 & 0.306 \\
\hline Paark Wald F statistic & 31.941 & 32.260 & 27.910 & 27.910 & 20.861 & 20.939 \\
\hline
\end{tabular}

All specifications include district and state-year fixed effects. Robust z-statistics in parenthesis; ***p<0.01, ** $p<0.05$, * $p<0.1$; urban population is instrumented through the number of urban immigrants from other states. 


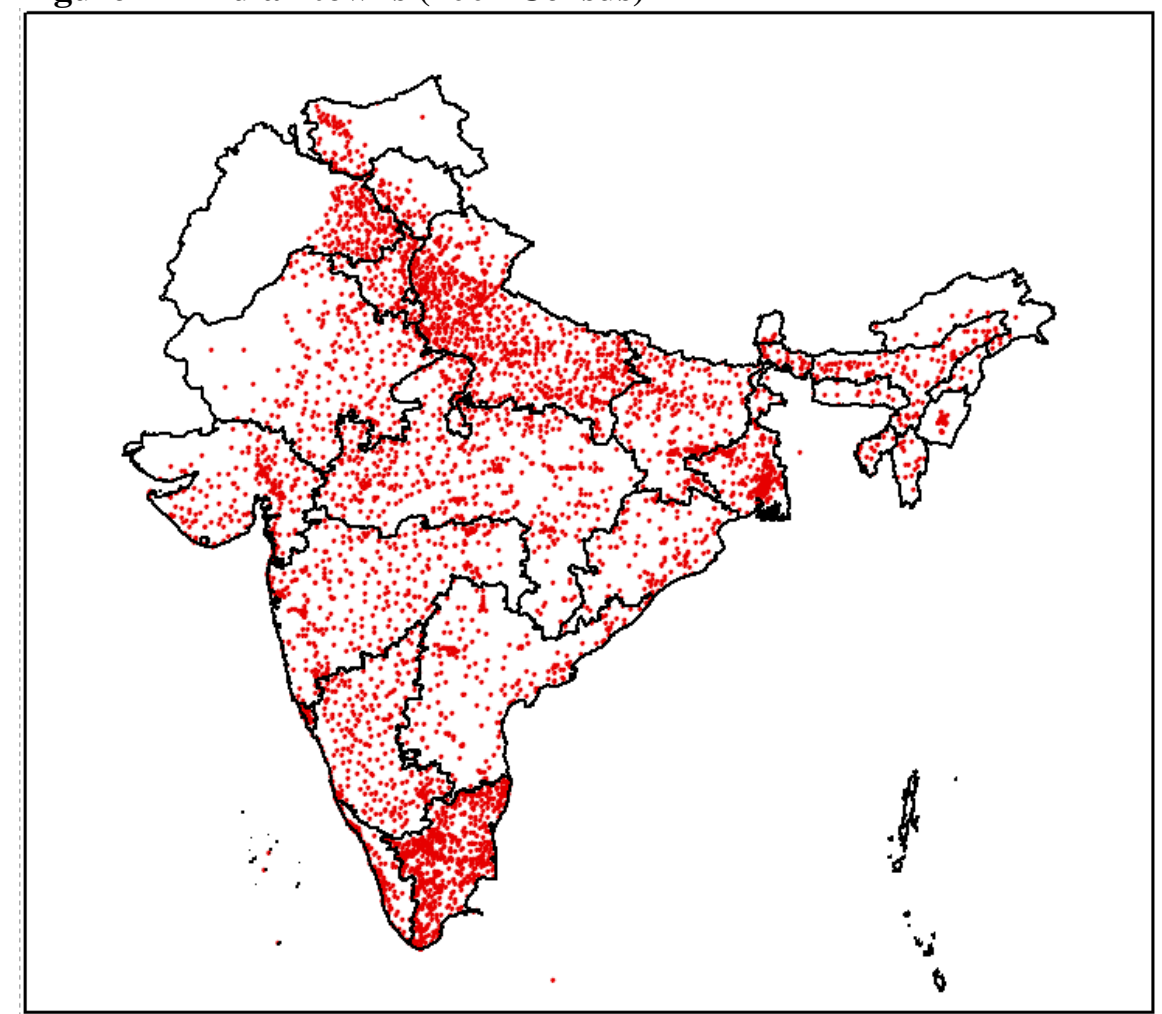

Note: the State of Delhi is excluded from the map

Source: Authors' elaboration on data from Indian Census 2001, and data on city spatial coordinates from Indian Gazetteer and GPSvisulizer,com.

Figure 2 - Urban population growth (\%) and poverty reduction, by district 1981-99

(a) Urban population growth $(\%), 1981-97$

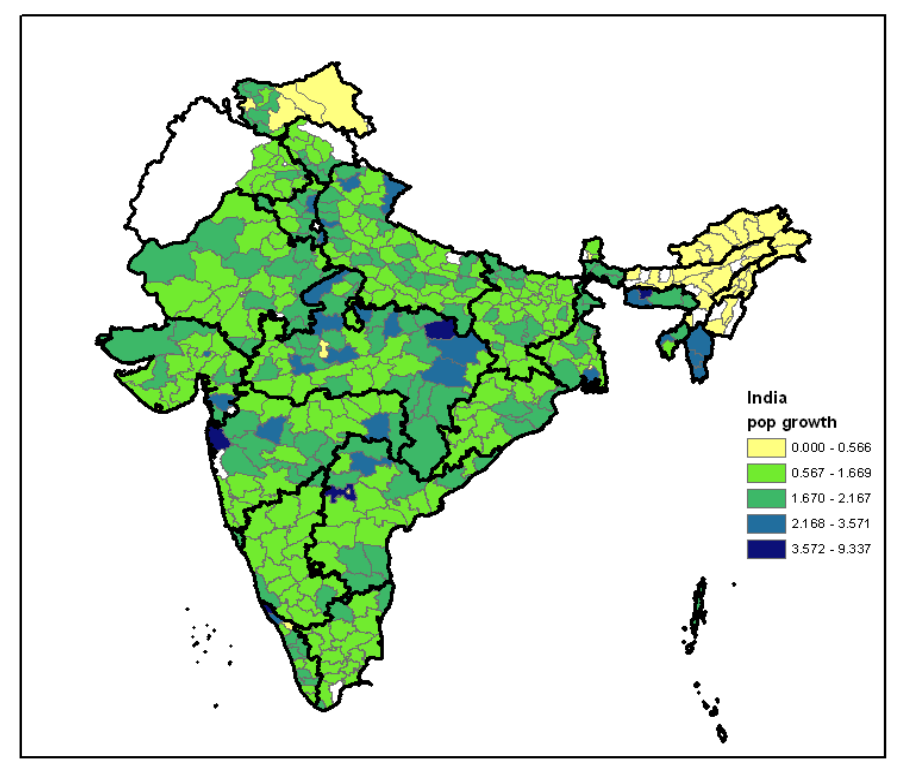

(b) Share of rural pop. lifted out of poverty, 1983-99

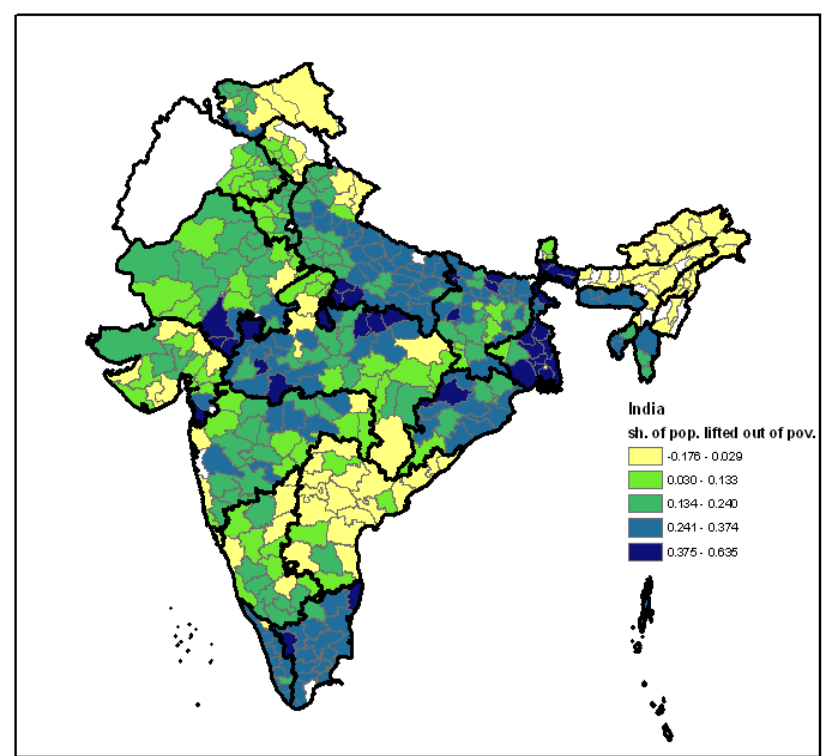

Note: the map (b) reports the difference between the district poverty share in 1983 and 1999. E.g., a value of 0.30 means that in 1983 the share of poor rural population was 0.3 bigger than in 1999. The State of Delhi is excluded from the map Source: Authors' elaboration on Indian Census and NSS (various rounds) 


\section{References}

Aghion P., Burgess R., Redding S. and F. Zilibotti (2007). The Unequal Effects of Liberalization: Evidence from Dismantling the License Raj in India, American Economic Review, forthcoming.

Baum, C., M. Schaffer and S. Stillman, (2008), IVREG2: Stata module for extended instrumental variables/2SLS and GMM estimation, Statistical Software Components from Boston College Department of Economics.

Becker, G.S. and K.M. Murphy, (1992). _The division of labor, coordination costs, and knowledge, Quarterly Journal of Economics, 107(4), pp. 1137-60.

Berdegue, J.A., E. Ramirez, T. Reardon, and G. Escobar (2001). Rural nonfarm employment and incomes in Chile, World Development, 29(3), pp. 411-425.

Birthal, P. (2007). Linking Smallholder Livestock Producers to Markets: Issues and Approaches, mimeo, Indian Society of Agricultural Economics.

Chandra Mohan Reddy, Y.V.R. (2000), A Study of Livestock Markets and Marketing of Livestock in Rangareddy District of Andhra Pradesh, MSc Dissertation, Department of Agricultural Economics, Acharya N.G. Ranga Agricultural University, Hyderabad.

Datt, G. and M. Ravallion (1998), Farm Productivity and Rural Poverty in India, FCND Discussion Paper No. 42, International Food Policy Research Institute, Washington D.C.

Datt, G. and M. Ravallion, (2002). Is India's economic growth leaving the poor behind?, Journal of Economic Perspective 16, 89-108.

Deichmann, U. F. Shilpi and R. Vakis, (2008). Spatial specialization and farm-non-farm linkages, Policy Research Working Paper 4611: The World Bank.

Deshingkar, P. (2005). Seasonal migration: How rural is rural?, ODI Opinions no. 52.

Deshingkar, P. and D. Start (2003). Seasonal Migration for Livelihoods in India: Coping, Accumulation and Exclusion, ODI Working Paper 220.

Dore, R. (1987). Taking Japan Seriously: A Confucian Perspective on Leading Economic Issues, Stanford University Press: Stanford.

Ellis, F., (1998). Household strategies and rural livelihood diversification, Journal of Development Studies, Vol. 35(1): 1-38.

Eswaran, M. A. Kotwal, B. Ramaswami, and W. Wadhwa (2008), How does poverty decline? Suggestive evidence from India, 1983-1999, mimeo.

Fafchamps, M. and F. Shilpi (2003).The spatial division of labor in Nepal, Journal of Development Studies 39(6): 23-66.

Fafchamps, M. and F. Shilpi, (2005). Cities and Specialization: Evidence from South Asia, Economic Journal, Vol. 115, April: 477-504.

Foster, A. and M. Rosenzweig, (2004). Agricultural productivity growth, rural economic diversity and economic reforms: India 1970-2000, Economic Development and Cultural Change, 52(3), p.509-542.

Fujita, M., P. Krugman, P., and A.J. Venables, (1999). The Spatial Economy: Cities, Regions, and International Trade, MIT Press: Cambridge and London.

Government of India, various years. Census of India. 
Hasan, R., D. Mitra and B.P. Ural, (2007). Trade Liberalization, Labor-Market Institutions and Poverty Reduction: Evidence from Indian States, India Policy Forum 3, pp. 71-122.

Jacobs, J., (1969). The Economy of Cities, Random House: New York.

Jha, V. (2008). Trickle down effects of Inter State Migration in a period of high growth in the Indian economy, mimeo.

Kijima, Y. and P. Lanjouw, (2003). Poverty in India during the 1990s: a regional perspective. World Bank Policy Research Working Paper 3141.

Kochar, A. (2004). Urban influences on rural schooling in India, Journal of Development Economics 74, pp. 113- 136

Kuznets, S., (1955). Economic Growth and Income Inequality, American Economic Review, 1, Vol. XLV.

Lanjouw, P. and A. Shariff (2002). Rural Nonfarm Employment in India: Access, income, and poverty impact. Working Paper Series no 81. New Delhi: National Council of Applied Economic Research.

Lewis, W. A., (1954). Economic development with unlimited supplies of labour, The Manchester School, 22: 139-191.

Matsuyama, K., (1992). Agricultural Productivity, Comparative Advantage, and Economic Growth," Journal of Economic Theory 58, pp. 317-334.

Nurske, R., (1953). Problems of capital formation in underdeveloped countries, Oxford University Press: New York.

Parthasarathy Rao,P., P.S. Birthal, P.K. Joshi and D. Kar (2004), Agricultural Diversification in India and Role of Urbanization, MTID Discussion Paper No. 77, IFPRI.

Plantinga, A.J., Lubowski, R.N. and R.N. Stavins (2002), The effects of potential land development on agricultural land prices, Journal of Urban Economics 52, 561-81.

Ravallion, M., (2002), On the urbanization of poverty, Journal of Development Economics $68,435-442$.

Ravallion, M., S. Chen and P. Sangraula, (2007). New evidence on the urbanization of global poverty, World Bank Policy Research Working Paper 4199.

Schaffer, M. (2007), XTIVREG2: Stata module to perform extended IV/2SLS, GMM and AC/HAC, LIML and k-class regression for panel data models, Statistical Software Components from Boston College Department of Economics

Stark, O. (1980). On the Role of Urban-Rural Remittances in Rural Development, Journal of Development Studies, 16(3): 369-74.

Stark, O.; and R.E.B. Lucas, (1988). Migration, remittances and the family, Economic Development and Cultural Change, Vol. 36 (3):465-482.

Stock, J.H. and M. Yogo, (2005). Testing for weak instruments in linear IV regression, in D.W.K. Andrews and J.H. Stock (eds.) Identification and Inference for Econometric Models: Essays in Honor of Thomas Rothenberg, Cambridge: Cambridge University Press, 2005.

Thanh, H.X., D.T., Thu Phuong, N. Thu Huong, and C. Tacoli (2008), Urbanization and rural development in Vietnam's Mekong Delta, IIED Working Paper 14.

Topalova, P., (2005). Trade Liberalization, Poverty, and Inequality: Evidence from Indian Districts, NBER Working Paper No. W11614. 
United Nations, (2008). World Urbanization Prospects: The 2007 Revision Population Database, http://esa.un.org/unup/, accessed 23 May 2008.

von Thünen, J. H., (1966). Isolated State: an English Edition of Der Isolierte Staat, Pergamon Press, Oxford.

World Bank, (2008). World Development Report 2008: Agriculture for Development, The World Bank: Washington DC. 


\section{BERR}

\section{Spatial Economics Research Centre (SERC)}

London School of Economics

Houghton Street

London WC2A 2AE

Tel: 02078523565

Fax: 02079556848

Web: www.spatialeconomics.ac.uk

SERC is an independent research centre funded by the Economic and Social Research Council (ESRC), Department for Business, Enterprise and Regulatory Reform (BERR), the Department for Communities and Local Government (CLG) and the Welsh Assembly Government. 